\title{
Os quatro momentos da leitura nietzschiana de Afrikan Spir ${ }^{*, * *}$
}

\author{
Paolo D'Iorio ${ }^{* * *}$
}

Resumo: A obra de Afrikan Spir é uma importante fonte para entender a discussão de Nietzsche com a filosofia crítica. Ele procura superar a crítica transcendental através de uma investigação genética sobre a origem dos conceitos; ao mesmo tempo, tenta revelar os preconceitos e as idiossincrasias que se ocultam por detrás da vontade de manter a cisão entre mundo fenomenal e mundo numenal. A aversão pela mudança, pelo vir-a-ser, pelo testemunho dos sentidos, a predileção por verdades lógicas e conceitos contraditórios constituem, segundo Nietzsche, a forma específica de superstição dos filósofos críticos, dos quais a filosofia de Spir é o exemplo mais consequente.

Palavras-chave: Spir, tradição transcendental, metafísica, incondicionado.

* Tradução do francês e do alemão: Eduardo Nasser. Nota do tradutor: originariamente, as citações em alemão neste texto não foram, em sua maior parte, traduzidas para o francês.

** Diretor de pesquisa no CNRS, Paolo D'Iorio é atualmente diretor do Instituto de textos e manuscritos modernos (CNRS / École normale supérieure, Paris). Uma primeira versão do presente artigo foi publicada como "La superstition des philosophes critiques. Nietzsche et Afrikan Spir" in: NietzscheStudien 22, 1993, p. 257-294.

*** École normale supérieure, Centre National de Recherche Scientifique, Paris, França.

ORCID https://orcid.org/0000-0002-2250-3851

Correio eletrônico: diorio@ens.fr 
D’Torio, P.

Dos sentidos provêm toda credulidade, Toda boa consciência, toda aparência de verdade

JGB/BM § 134

Há tempos estudar as fontes e as leituras de Nietzsche tem se revelado um dos campos mais profícuos para reconstruir, num nível mais aprofundado, o pensamento nietzschiano. Um estudo dessa natureza não irá e nem pode desvalorizar a sua originalidade filosófica, pelo contrário, revela-se um conhecimento indispensável para poder efetivamente compreender a profundidade dessa originalidade. De fato, muitas vezes o texto de Nietzsche, isoladamente, acaba não sendo plenamente suficiente para isso. Com efeito, por trás da aparente simplicidade do texto, inteiros caminhos especulativos que Nietzsche percorreu muitas vezes correm o risco de se esconder, e, apenas conhecendo-os é possível iluminar os resultados aos quais ele chegou e que o texto apenas expõe. As leituras realizadas por Nietzsche representam, assim, o contexto que agrega uma imprescindível e ulterior dimensão ao texto.

Isso não vale apenas para as leituras mais conhecidas e evidentes, mas diz respeito, talvez em maior medida, às leituras das quais o texto nietzschiano revela poucos e tênues vestígios. Esse é certamente o caso do estudo que Nietzsche realizou sobre o pensamento de Afrikan Spir ${ }^{1}$, mesmo que raramente citado, está constantemente presente nas reflexões gnoseológicas que trespassam todo o percurso da filosofia nietzschiana, de 1872 a 1888.

Pode-se colocar em evidência, em particular, quatro momentos onde, nos textos nietzschianos, a influência de Spir se manifesta mais claramente.

\footnotetext{
1 Africàn Aleksàndrovic Spir, (Elisavetgrad, Ucrânia) 15 novembro 1837, Genebra, 26 março 1890). Ele estudou em Leipzig, Tübingen e Stuttgart, para depois se estabelecer na Suíça. Em 1873 ele publica sua obra fundamental: Denken und Wirklichkeit. Versuch einer Erneuerung der kritischen Philosophie. Essa obra foi publicada em quatro edições, com uma tradução em francês da terceira edição (Spir, Afrikan. Pensée et Réalité. Essai d'une réforme de la philosophie critique, Lille: Tallandier, 1896), seguido de outros volumes sobre temas teoréticos e morais em alemão e francês, e reunidos pelo autor nos Gesammelte Schriften, 4 vol., Leipzig 1883-85 (reeditados com uma nota biográfica da filha do autor nas Gesammelte Werke, 2 vol., Leipzig 1908).
}

12 | Cad. Nietzsche, Guarulhos/Porto Seguro, v.42, n.2, p. 11-60, maio/agosto, 2021. 
Em 1869, Spir publica seu Investigação sobre a certeza do conhecimento da realidade, que Nietzsche adquire pouco depois. ${ }^{2} \mathrm{~A}$ leitura dessa obra deixa seus traços nos fragmentos póstumos desse período e, provavelmente, influencia também a redação do texto curto, porém importante, Sobre verdade e mentira no sentido extramoral, no qual Nietzsche se opõe claramente a Spir e enuncia, pela primeira vez, seu ceticismo no concernente ao valor de verdade dos conceitos. Em 1873 Spir reelabora seu volume de 1869, até compor sua obra fundamental: Pensamento e realidade. Ensaio de uma reforma da filosofia crítica, obra que desperta imediatamente o interesse de Nietzsche e que ele retira da biblioteca da Basileia. ${ }^{3}$ Encontra-se uma primeira referência desse texto na última versão do escrito póstumo A filosofia na época trágica dos gregos (1873), onde Spir é citado no contexto de uma discussão sobre a idealidade do tempo.

A segunda edição (revisada) de Pensamento e realidade é publicada em 1877 e Nietzsche, que se encontra em Sorrento, pede ao seu editor que lhe envie um exemplar. ${ }^{4}$ Nesse período, Nietzsche utiliza, sobretudo, a definição spiriana de metafísica enquanto "incondicionado", bem como as observações sobre a relação

2Spir, Afrikan. Forschung nach der Gewissheit in der Erkenntniss der Wirklichkeit, Leipzig: Förster \& Findel, 1869, pp. 346 (abreviado doravante $F G$ ). A leitura dessa obra é confirmada pelo conteúdo do caderno P I 20, verão de 1872 - início de 1873 (cf. Schlechta, Karl e Anders, Anni. Friedrich Nietzsche. Von den verborgenen Anfängen seines Philosophierens, Stuttgart: Frommann, 1962, p. 119).

3 Spir, Afrikan. Denken und Wirklichkeit. Versuch einer Erneuerung der kritischen Philosophie, Leipzig: Findel 1873, 2 vol., pp. 469, 257 (abreviado doravante DW 1873); cf. Max Oehler, Nietzsches Bibliothek, Vierzehnte Jahresgabe der Gesellschaft der Freunde des Nietzsche-Archivs, apêndice 2: "Verzeichnis der von Nietzsche aus der Universitätsbibliothek in Basel 1869-1879 entliehenen Bücher", Weimar 1942, p. 51 sq.

4Spir, Afrikan. Denken und Wirklichkeit. Versuch einer Erneuerung der kritischen Philosophie, Leipzig: Findel 1877, 2 vol., pp. 386, 292 (abreviado doravante $D W$ ); cf. o cartão postal enviado de Sorrento para Ernst Schmeitzer no dia 2 de fevereiro de 1877. O exemplar de Nietzsche, que consultamos na Zentralbibliothek der deutschen Klassik de Weimar, é rico em expressões sublinhadas, traços nas margens e anotações, o que prova o interesse de Nietzsche por essa obra. Lamentavelmente muitas anotações não são decifráveis, pois, após a encadernação providenciada pelo Nietzsche-Archiv anterior, o formato das páginas da maior parte dos volumes foi reduzido, causando a perda total ou parcial das palavras escritas por Nietzsche na margem. 
D'Torio, P.

entre mundo numenal e mundo fenomenal. A obra de Spir contribui também para a gestação de Humano, demasiado humano, e é possível se deparar com a influência em certos pontos cruciais nos quais Nietzsche tenta naturalizar a crítica transcendental, substituindo-a por uma história da gênese do pensamento.

Durante o verão de 1881, em Sils-Maria, quando, então, nasce em seu espírito o pensamento do eterno retorno do mesmo, Nietzsche se ocupa novamente com a origem e a justificação do conhecimento. Muito rapidamente ele sente a necessidade de retornar às páginas de Pensamento e Realidade. ${ }^{5}$ Tomando como referencial polêmico a doutrina spiriana do conceito de incondicionado, Nietzsche aprofunda a reflexão sobre a estrutura da aparência e ultrapassa essa "antinomia fundamental" que manifesta, segundo Spir, o fracasso inevitável de toda tentativa de explicar o mundo.

Durante os anos 1880, a linguagem de Spir se torna uma parte integrante das meditações gnoseológicas nietzschianas e, nos cadernos póstumos, nós encontramos referências contínuas a conceitos e fórmulas spirianas. Mas, durante o verão de 1885, sempre em Sils Maria, a confrontação com o texto de Spir (que Nietzsche lê ao mesmo tempo que $O$ mundo real e o aparente de Gustav Teichmüller) ${ }^{6}$ se faz agora de forma mais próxima. Nietzsche está em vias de desenvolver o projeto de um sistema filosófico consagrado à vontade de potência como nova interpretação de todo vir-a-ser. Paralelamente, ele trabalha com uma reelaboração de Menschliches, Allzumenschliches, utilizando

5 Cf. carta a Overbeck do dia 20/21 agosto de 1881, KSB 6. 116 - 118.

6 Teichmüller, Gustav. Die wirkliche und die scheinbare Welt. Neue Grundlegung der Metaphysik, Breslau: Koebner, 1882, pp. 357. O texto desse autor, que aparece muitas vezes no Nachla $\beta$ nietzschiano, não se encontra na biblioteca póstuma de Nietzsche, pois os dois livros filosóficos de Teichmüller ( $O$ mundo real e o aparente e Novos estudos sobre o conceito) pertenciam a Overbeck, $\mathrm{e}$ estão provavelmente conservados (com as anotações de Nietzsche — se elas existem) no Nachlaß de Overbeck na Basileia. Cf. as cartas a Overbeck do dia 2 de julho de 1885 e do dia 12 de novembro de 1885, KSB 7. 61-63, 109.

14 | Cad. Nietzsche, Guarulhos/Porto Seguro, v.42, n.2, p. 11-60, maio/agosto, 2021. 
e meditando novamente sobre o conteúdo do M III 1, caderno no qual estão transcritas as reflexões gnoseológicas do verão de $1881 .^{7}$ É no interior desse fervor teórico que se deve recolocar a discussão sobre a possibilidade de alcançar certezas imediatas. Segundo Nietzsche, nem o testemunho da consciência (como defende Spir ao retomar o cogito, ergo sum cartesiano), nem a intuição intelectual (proposta por Teichmüller) podem fornecer acesso. Os princípios a priori e a legitimidade de uma extensão ontológica das leis lógicas são, mais uma vez, os alvos da crítica nietzschiana. A crítica transcendental é novamente superada por uma investigação genética sobre a origem dos conceitos; mas, ao mesmo tempo, Nietzsche tenta revelar os preconceitos e as idiossincrasias que se ocultam por detrás da vontade de manter a cisão entre mundo fenomenal e mundo numenal. A aversão pela mudança, pelo vir-aser, pelo testemunho dos sentidos, a predileção por verdades lógicas e conceitos contraditórios (tais como "mundo verdadeiro", "ser", "incondicionado", "conhecimento absoluto"), constituem, segundo Nietzsche, a forma específica de superstição dos filósofos críticos, dos quais a filosofia de Spir é o exemplo mais consequente. ${ }^{8}$

\section{A leitura de 1873}

O primeiro contato de Nietzsche com a obra de Spir ocorreu em 1873. Após ter inflamado a corporação dos filólogos com a publicação de $O$ nascimento da tragédia, e antes de conceber o projeto das Considerações extemporâneas, aparece no pensamento nietzschiano um curso subterrâneo de reflexões teóricas. Essas reflexões recuperam em

7 Por exemplo, o fragmento 36[15] de 1885, derivado dos fragmentos 11[292, 345] de 1881; o fragmento $36[23]$ de 1885, derivado dos fragmentos $11[150,281]$ de 1881; o fragmento 35[53] de 1885, derivado do fragmento 11[70], e assim por diante. Cf. também o fragmento 42[3] de 1885, que resume as metaphysica desse período como primeira parte de Humano, demasiado humano.

8 Cf. Nachlass/FP 34[28], KSA 11. 429. Der Aberglaube der kritischen Philosophen (A superstição dos filósofos críticos) está no Nachlass/FP 44[1], KSA 11. 705, um capítulo de um dos numerosos planos para Der Wille zur Macht.

Cad. Nietzsche, Guarulhos/Porto Seguro, v.42, n.2, p. 11-60, maio/agosto, 2021.| 15 
D'Torio, P.

parte os comentários filosóficos do período de Leipzig e contrastam com a atividade metafísica, estética e propagandista de homem público que Nietzsche conduzia ao lado de Wagner, em favor da causa de Bayreuth. Essa atividade filosófica "secreta" — cujos traços estão entre os fragmentos póstumos que vão do verão de 1872 até a primavera de 1873, e, sobretudo, no importante caderno P I 20 — se apresenta como uma reflexão cética sobre os fundamentos e as diferentes formas possíveis de filosofia. Ela ganha forma em dois escritos póstumos redigidos em abril (A filosofia na época trágica dos gregos) e durante o verão de 1873 (Sobre verdade e mentira no sentido extra-moral). Participam, também, desse processo de elaboração teórica, Pesquisa sobre a consciência e o pensamento de Afrikan Spir.

1. Ainda que K. Schlechta e A. Anders considerassem como fundamental a influência de Spir ${ }^{9}$, Anthonie Meijers, num artigo muito interessante, nos indica a fonte principal de Sobre verdade $e$ mentira no sentido extra-moral na obra de Gustav Gerber, A linguagem como arte. ${ }^{10}$ Isso nos permite melhor compreender o papel que Spir desempenhou no interior do laboratório teórico nietzschiano.

Segundo Gerber, a linguagem e as categorias da razão nascem não de processos lógicos, mas da criação artística de figuras de retórica, como as metonímias, as metáforas e as sinédoques. No

9"Nietzsche obtém, através de Spir, uma apresentação detalhada dos problemas relevantes da teoria do conhecimento. Parece-me que o novo ponto de vista de Nietzsche sobre as ciências da natureza em Sobre verdade e mentira no sentido extra-moral repousa sobre esse preciso conhecimento a respeito da situação fundamental. Por outro lado, isso me parece ser a causa para que Nietzsche, nesse ensaio, tenha desenvolvido sua questão pela verdade primordialmente enquanto um problema da linguagem" (Schlechta e Anders, 1962, p. 121).

10 Cf. Meijers, Anthonie, "Gustav Gerber und Friedrich Nietzsche. Zum historischen Hintergrund der sprachphilosophischen Auffassungen des frühen Nietzsche", Nietzsche Studien, 17 (1988), p. 367-390. Infelizmente, a análise meticulosa e bem fundamentada de A. Meijers restringe-se às lições sobre retórica e Sobre verdade e mentira no sentido extra-moral, enquanto que, a nosso ver, os fragmentos póstumos desse período (por exemplo Nachlass/FP 19[66, 67, 135, 204, 209, 210, 215-217, 224, 226-229, 236, 242, 249], KSA 7.440, 441, 463, 481-484, 486, 487, 489-493, 495, 498) parecem igualmente conectados com a filosofia da linguagem de Gerber. No mais, seria interessante realizar uma investigação sistemática da influência de Gerber sobre todo corpus da obra de Nietzsche, como deseja, aliás, A. Meijers no fim de seu artigo (p. 390).

16 | Cad. Nietzsche, Guarulhos/Porto Seguro, v.42, n.2, p. 11-60, maio/agosto, 2021. 
fragmento póstumo 19[242], Nietzsche aplica essas mesmas reflexões sobre os juízos sintéticos - considerados pela filosofia crítica, e por Spir em particular, como fontes do conhecimento —, interpretandoos como um caso particular de metonímia, na qual a essência e os efeitos de uma coisa são confundidos.

Spir, Forschung nach der Gewissheit, p. 13.

Mas encontramos sem dúvida muitas coisas cuja essência não pode se expressar com o enunciado "A é A". Que representação alguém poderia ter da essência de um lápis, por exemplo, se lhe fosse dito: o lápis é o lápis? Claramente nenhuma. Para descrever o lápis, se teria de expressar mais ou menos assim: o lápis é uma coisa extensa, longa, fina, cilíndrica, colorida, dura, pesada, etc. Vemos aqui portanto numa unidade (o lápis) conter, incluir, uma grande quantidade de propriedades, todas diferentes entre si.

A unidade do diverso se chama em geral uma síntese, e os enunciados nos quais a essência dessa unidade é expressa se chamam enunciados ou juízos sintéticos. A forma geral dos enunciados sintéticos, a expressão geral de uma síntese, é "A é B"].
Nietzsche, Nachlass/FP 19[242],

KSA 7. $495-496$.

A essência da definição: o lápis é um corpo longo, etc. A é B. $\mathrm{O}$ que é longo é aqui também colorido. As propriedades contêm apenas relações.

O conceito "lápis" é confundido com a "coisa" lápis. Esse "é" no juízo sintético é falso, ele contém uma transposição, duas esferas distintas, entre as quais uma igualação nunca pode ocorrer, são colocadas lado a lado] ${ }^{11}$.

\section{A partir da união do diverso no juízo sintético, Spir deduz o} caráter não autêntico do mundo fenomenal, dominado pela união contraditória do diverso. Ele então começou a prospecção de um domínio no qual se manifesta a pureza da realidade verdadeira, caracterizada pela identidade consigo mesma. ${ }^{12}$

11 Cf. também o fragmento póstumo 19[215] do verão 1872 - início de 1873, KSA 7.486, no qual se reconhece mais claramente a influência de Gerber: "Um predicado é confundido com uma soma de predicados (definição). [...] Todas as figuras de retórica (isto é, a essência da linguagem) são conclusões lógicas falsas. Assim começa a razão!”.

12 "É claro que a realidade efetiva, que é um acontecimento, não é coincidente com o conceito de realidade, pois justamente todo acontecimento é um tanto contraditório e, segundo o conceito, é realidade $=$ identidade consigo mesma. No contexto em que tudo que é contraditório ocorre enquanto um acontecimento, temos uma flagrante confirmação da visão apriorística” (Spir, Afrikan. FG, p. 15). 
D'Torio, P.

Ao contrário, Nietzsche, utilizando para a filosofia transcendental a análise de Gerber, abre uma discussão crítica sobre a estrutura da linguagem e sobre os limites e a legitimidade da conceitualização. $\mathrm{O}$ juízo sintético não é, segundo Nietzsche, a origem do conhecimento (Kant), nem a demonstração do caráter ilusório do mundo fenomenal (Spir): trata-se de uma falsa definição da coisa a partir da soma de suas propriedades.

Nos anos de 1880, Nietzsche desmascara as diferentes formas pelas quais se materializa o erro que ele já denunciara em suas notas de juventude: a troca do conceito de objeto com a causa de suas propriedades. ${ }^{13}$ Essas reflexões redundam no famoso exemplo do relâmpago. Quando digo "o relâmpago relampeja", eu considerei o fato do relampejar uma vez como atividade e uma vez como sujeito. Crer no sujeito significa, assim, redobrar o "fazer" em "fazer fazer", quer dizer, considerar o mesmo evento primeiro como causa e em seguida como efeito desta: separar o relâmpago de seu brilho e considerar esse último como produto de um sujeito chamado "relâmpago". Como se, uma vez o agente privado da faculdade de fazer, ele continuasse, contudo, existindo, como se por debaixo da força houvesse um substrato indiferente ao qual seria permitido manifestar ou não manifestar essa força. Mas esse substrato não passa de uma invenção, uma suposição primitiva e falsa incorporada à linguagem. ${ }^{14}$

2. Na obra póstuma A filosofia na época trágica dos gregos, Nietzsche considera os filósofos pré-platônicos como um repertório de modelos de pensamentos ${ }^{15}$ e entrelaça, implicitamente, a narrativa

13 Sobre esse tema, é interessante comparar o Nachlass/FP 19[236], KSA 7.494: "Quando a coisa 'age', isso quer dizer: nós consideramos todas as restantes propriedades que, em caso contrário, não existiriam aqui e, momentaneamente, estão latentes, enquanto causa que faz emergir uma propriedade individual: quer dizer, nós tomamos a soma de suas propriedades — $\mathrm{x}$ enquanto causa da propriedade $x$ : o que é completamente estúpido e insano!” (Nachlass/FP 2[87], KSA 12.105).

14 No concernente às formulações de maturidade, cf. Nachlass/FP 2[83, 84, 139], KSA 12.101-104, 135 e 136, Nachlass/FP 7[1], KSA 12. 247 -250 e, num outro contexto: GM/GM, I, 13.

15 “ As intuições originais desses filósofos são as mais elevadas e mais puras que já foram alcançadas. Os homens mesmos são encarnações formais da filosofia e suas variadas formas " (Nachlass/FP 14[28], KSA 7. 387).

18 | Cad. Nietzsche, Guarulhos/Porto Seguro, v.42, n.2, p. 11-60, maio/agosto, 2021. 
do desenvolvimento da filosofia pré-platônica com uma crítica das principais posições teóricas dos seus contemporâneos.

Por exemplo, a figura de Anaximandro recebe os caráteres do pessimismo schopenhaueriano, as filosofias de Heráclito e Demócrito pressagiam os futuros desenvolvimentos do pensamento nietzschiano e a interpretação de Parmênides é obtida por meio de uma confrontação complexa com a filosofia de Spir. ${ }^{16}$

Convencido de que um "único sistema bem demonstrado possui mais valor na filosofia que dez sistemas inteiros", Spir considera a investigação da certeza como o dever principal da filosofia. ${ }^{17}$ Segundo Nietzsche, "a terrível energia dessa aspiração à certeza em uma época extremamente móvel e fantástica, que pensava miticamente", é igualmente surpreendente em Parmenides. ${ }^{18}$

Em segundo lugar, Spir e Parmênides atribuem a mesma função ao princípio de identidade, que eles consideram não somente um princípio lógico e analítico, mas um princípio sintético que cumpre a função de discriminante ontológico. De acordo com Spir, é somente no caso em que a realidade se apresenta constantemente igual a ela mesma que o princípio "cada coisa é igual a ela mesma" poderia ser considerado como uma simples tautologia; mas "o conceito do real ou do efetivo de um lado, e aquele do idêntico a si de outro, não são o mesmo conceito, mas dois conceitos diferentes. Consequentemente, o princípio de identidade, que exprime uma ligação entre esses dois conceitos, não é um princípio analítico, mas um princípio sintético". Enquanto princípio sintético, o princípio de identidade nos revela a verdadeira essência das coisas, nos diz que somente

16 Num dos numerosos rascunhos preparatórios, Nietzsche pensou em utilizar também certas indicações de Spir para caracterizar Anaximandro; cf. Nachlass/FP 26[1], KSA 7.571, que reenvia à página 431 do primeiro tomo de Pensamento e realidade - e não à página 276, como diz Schlechta $\mathrm{e}$ Anders (op. cit. p. 94).

17 Spir, Afrikan. FG, p. III. A obra começa com estas palavras: "O objetivo que coloquei para minha investigação, foi, como diz o título, a certeza ". Cf. também DW 1873 I, p. 27.

18PHG/FT 11, KSA 1. 845. Cf. também o fragmento preparatório 23[12], KSA 7. 543. 
D'Torio, P.

aquilo que é idêntico a si é dotado de verdadeira realidade e que, consequentemente, todo conteúdo de nossa experiência, na qual se manifesta uma união do diverso, não pode ser real. ${ }^{19}$

Da mesma forma, o Parmênides de Nietzsche crê no alcance ontológico do princípio de identidade até dissolver completamente a realidade do mundo da experiência. Quando - após haver descoberto na tautologia $\mathrm{A}=\mathrm{A}$ a única forma de conhecimento pela qual se pode ter uma confiança absoluta, e após haver feito dela a chave para descobrir o segredo do mundo - Parmênides volta novamente seu olhar para o mundo do vir-a-ser, colocando-se em cólera por enxergar que todas as percepções dos sentidos não nos fornecem senão enganos, "e seu principal engano consiste precisamente em nos fazer crer que mesmo o que não é existe, quer dizer, que o vira-ser possui um ser" (PHG/FT 10, KSA 1.843).

Um terceiro ponto de encontro entre Spir e o Parmênides de Nietzsche se localiza na prova do caráter a priori das leis lógicas (quer dizer, do princípio de identidade e de não contradição) a partir do não-acordo com o testemunho dos sentidos. Segundo Spir, o profundo desacordo entre o conceito de objeto, tal como ele é expresso pelas leis lógicas, e a composição empírica dos objetos, refere necessariamente a um lado da realidade para além do domínio dos sentidos: "a experiência mesma, não estando em acordo com as leis lógicas, testemunha a validade objetiva destas últimas". ${ }^{20}$

Segundo Parmênides, a verdadeira realidade é aquela do ser esférico, único, imóvel, limitado, indivisível, finito, subtraído de

19Spir, Afrikan. DW 1873, I, p. 195; cf. também p. 336.

20 Spir, Afrikan. DW 1873, I, p. 235. Esse conceito será expresso de modo mais incisivo na segunda edição (cf. DW I, p. 232; as expressões sublinhadas correspondem àquelas que se encontram no exemplar de Nietzsche): "O critério efetivo da origem a priori de um entendimento geral consiste em que ele não é somente necessário para o pensamento e é certo em si, mas também em que esses princípios ou elementos não estão contidos em nenhuma experiência fática e comprovável e que não são coincidentes com dados empíricos" [...] Eu demonstrei que, nas sentenças lógicas da identidade e da contradição, mesmo este conceito se expressa a partir da essência própria, incondicionada das coisas, o qual não poderia jamais provir da experiência, pois os dados da experiência não coincidem com ele, porém, atestam sua validade objetiva justamente por essa não-coincidência".

20 | Cad. Nietzsche, Guarulhos/Porto Seguro, v.42, n.2, p. 11-60, maio/agosto, 2021. 
nascimento e morte, que coincide e se identifica com os imperativos do pensamento: "É justamente isso que, com efeito, nos garante que ela não foi deduzida dos sentidos" (PHG/FT 12, KSA 1.850).

Contudo, é interessante destacar o uso ambivalente que Nietzsche faz da filosofia de Spir, pois, em A filosofia na época trágica dos gregos, ela serve para caracterizar a figura de Parmênides e, ao mesmo tempo, para refutar sua filosofia. A posição geral da filosofia spiriana é contrária à justificação do vir-a-ser para a qual tende continuamente a filosofia de Nietzsche, mas, frequentemente, como teremos a oportunidade de destacar em seguida, Nietzsche usará a penetrante força lógico-argumentativa contida em certas passagens do livro de Spir para desbancar outros tipos de concepções mais especificamente metafisicas.

Vejamos, por exemplo, de que maneira Nietzsche utiliza, para refutar a doutrina parmenídica do caráter ilusório do movimento (e a noção kantiana e schopenhaueriana da idealidade transcendental do espaço e do tempo), o parágrafo "Sobre a essência da mudança", retirado de Pensamento e realidade. ${ }^{21}$

Ao falar da força dos argumentos parmenídicos contra o movimento, Nietzsche faz Parmênides dizer:

Não pode ser dado nem tempo, nem movimento, nem espaço, pois só podemos pensá-los como infinito, com efeito, por um lado, infinitamente grandes, em seguida, infinitamente divisíveis; tudo que é infinito, contudo, não possui ser, não existe", o que ninguém duvida desde que o sentido da palavra ser seja apreendido rigorosamente e que se considere impossível a existência de algo contraditório, por exemplo, uma infinitude consumada. (PHG/FT 12, KSA 1.856).

Nessa afirmação do Parmênides de Nietzsche, se encontram os traços de uma passagem de Schopenhauer que demonstrou a impossibilidade da existência de séries infinitas — temporais,

21 Cf. Spir, Afrikan. DW 1873, I, p 261 sq., e Nietzsche, PHG/FT 15, KSA 1.857 sq. 
espaciais ou causais — fora da representação do sujeito. Se a série causal nos parece infinita, diz Schopenhauer, isso não depende da conformação das coisas nelas mesmas (porque uma coisa existente não poderia jamais ser infinita) ${ }^{22}$, mas depende da estrutura cognitiva do sujeito, que enxerga como ilimitado e em movimento isso que, na realidade, é imóvel e atemporal.

$\mathrm{O}$ fato de que o infinito não pode existir em si, mas somente numa série de representações sucessivas, leva Schopenhauer a reconhecer a idealidade transcendental do fenômeno por uma via diferente — mas convergente — daquela seguida por Kant. Comparemos os textos de Kant e Schopenhauer, começando com o de Kant:

Se o mundo é uma totalidade existente, ou ele é finito ou infinito. Agora, tanto a primeira quanto a segunda alternativa são falsas [...] Portanto, também é falso que o mundo (o conjunto de todos os fenômenos) seja uma totalidade existente. Donde se segue que os fenômenos em geral nada são fora de nossas representações, e é isso que queremos dizer com a sua idealidade transcendental. ${ }^{23}$

\section{Schopenhauer:}

Pg. 506; V. 534: Kant deseja, a partir do caráter incorreto das duas partes (quer dizer, a partir da insustentabilidade tanto da tese, quanto da antítese, da primeira antinomia cosmológica), demonstrar a idealidade transcendental do fenômeno e começa assim: "Se o mundo é uma totalidade existente em si, então é finita ou infinita" - Mas isso é falso: uma totalidade existente em si não pode de modo algum ser infinita. — Em vez disso, aquela idealidade poderia ser deduzida da infinitude de séries no mundo, do seguinte modo:

22 Schopenahuer, Arthur. Die Welt als Wille und Vorstellung in Sämtliche Werke, Leipzig: Brockhaus 1938, primeiro tomo, p. 591, 593: "O conceito de uma série infinita é, sem dúvida, contradita pela ideia que ela possa ser dada como uma totalidade [...] Entende-se erroneamente a si mesmo, quando se acredita pensar num infinito, seja qual for o tipo, como algo existente, objetivo, um quid atual". Aristóteles, a quem se refere Schopenhauer, já havia demonstrado que um infinito, seja qual for sua natureza, não pode ser pensado actu, mas somente potentia (cf. Aristóteles, Physique III, § 5, 204a 22 et III, § 6, 206a 13).

23 Kant, Immanuel. Kritik der reinen Vernunft, B 534-535.

22 | Cad. Nietzsche, Guarulhos/Porto Seguro, v.42, n.2, p. 11-60, maio/agosto, 2021. 
se as séries de razões e consequências no mundo não têm fim, então o mundo não pode ser uma totalidade independente da representação: pois esta supõe sempre limites determinados, assim como, por outro lado, as séries infinitas supõem um regressus infinito. Por isso, a suposta infinitude das séries deve ser determinada pela forma da razão e consequência, e essa pelo modo de conhecimento do sujeito, de forma que o mundo, tal como é conhecido, existe somente na representação do sujeito. ${ }^{24}$

Contudo, continua Nietzsche em A filosofia na época trágica dos gregos, é possível fazer ao menos uma objeção aos eleatas (e, ao mesmo tempo, à idealidade transcendental kantiana e schopenhaueriana do fenômeno), destacando que, tal como as impressões dos sentidos, o pensamento também está em movimento, um movimento de conceito para conceito. Como interpretar esse fato adquirido? Ou bem nós sustentamos que o movimento do pensamento testemunha a realidade da mudança em geral, ou bem nós sustentamos que o mundo interior e nosso pensamento não passam, eles também, de uma ilusão que não existe, assim como o mundo exterior. Mas, de acordo com essa segunda hipótese, nós não podemos condenar os sentidos em nome da razão, pois a razão é afetada pelos mesmos paradoxos que submetem o mundo sensível. Nos dois casos, a negação parmenídica do movimento é reconduzida ao absurdo.

Mas Parmênides, segundo Nietzsche - que inclui nesse ponto Spir, inserindo no texto de A filosofia na época trágica dos gregos uma longa citação retirada de Pensamento e realidade — poderia ter escapado desse impasse utilizando a resposta que Kant deu a uma

24 Deve-se apontar que a argumentação de Schopenhauer não pode valer para o espaço, e seguramente não para o tempo: o tempo não pode ser considerado existente e infinito senão às custas de uma contradição, pois trata-se de uma dimensão da realidade que não pode jamais ser dada em sua totalidade através de uma única intuição. Em sua maturidade, Nietzsche pensará o mundo limitado no que diz respeito ao espaço (um espaço que coincide com a quantidade de força), mas continuamente sujeito a uma mudança chamada "tempo" ou "temporalidade" (cf. por exemplo Nachlass/FP 35[55], KSA 11.526: "Recusar o "atemporal". Num determinado instante da força é dada a condicionalidade absoluta de uma nova repartição de todas suas forças: ela não pode permanecer imóvel. "Mudança" faz parte de sua essência, e, portanto, também a temporalidade: pelo qual, contudo, se coloca novamente, conceitualmente, a necessidade da mudança”. 
D'Torio, P.

objeção semelhante: nosso pensamento não se move, e aquilo que nos parece uma sucessão de representações não passa da representação de uma sucessão: "Eu posso muito bem dizer que nossas representações são sucessivas, mas isso apenas quer dizer que temos consciência delas como numa sequência de tempos, isto é, segundo a forma do sentido interno. O tempo não é por isso algo em si, nem mesmo uma determinação objetivamente inerente às coisas". Deve-se, portanto, de acordo com Nietzsche, distinguir o pensamento puro — situado numa dimensão atemporal — da consciência desse pensamento, que seria a tradução em termos de aparência, quer dizer da sucessão, da pluralidade, do movimento. ${ }^{25}$

A essa fina objeção, os adversários dos eleatas respondem como Spir respondia a Kant, quer dizer, sustentando que a sucessão que nós encontramos em nossas representações não pode ser uma pura aparência. Com efeito: 1) a sucessão das representações não pode ser identificada com a representação de sua sucessão, e essa última não pode ser possível se não afirmarmos a existência da primeira e, logo, a existência de um movimento real de nosso pensamento (cf. DW 1873, I, p. 264); 2) a crítica da razão tem como fundamento o fato de que as representações são como nos aparecem, sem o que toda investigação transcendental perde seu valor objetivo: portanto, se as representações nos aparecem em movimento, elas realmente devem estar em movimento (cf. DW 1873, I, p. 256).

Aqui termina a citação que Nietzsche faz de Spir, e o leitor poderia crer que Nietzsche e Spir estão de acordo por refutarem a idealidade do tempo kantiana em nome de uma filosofia do vir-a-ser. Na realidade, Spir continua dando razão ao intento kantiano de negar a realidade do tempo, pois o tempo é uma "pura abstração extraída da sucessão real e não pode ser imaginado sem ela", especificando

25Spir, Afrikan. DW 1873 I, p. 264, que cita I. Kant, Kritik der reinen Vernunft, B 54, nota; citados por Nietzsche em PHG/ FT 15, KSA 1.857; cf. também o Nachlass/FP 23[12], KSA 7.543.

24 | Cad. Nietzsche, Guarulhos/Porto Seguro, v.42, n.2, p. 11-60, maio/agosto, 2021. 
somente que isso não significa contestar a realidade da sucessão no mundo fenomenal. ${ }^{26}$

Procuremos melhor formular a posição de Spir perseguindo seu raciocínio. Como vimos, a validade dos conceitos a priori, e principalmente do conceito de incondicionado, é deduzido, segundo Spir, de seu desacordo com a experiência. Um dos testemunhos mais explícitos desse desacordo entre o mundo da experiência e o conceito da essência única e incondicionada das coisas é precisamente o fato de que a experiência é um puro vir-a-ser, uma alternância de ser e não-ser, submetida ao movimento, à mudança, possuindo um caráter transitório. ${ }^{27} \mathrm{~A}$ consciência do caráter ilusório da experiência, que foi afirmada energicamente por alguns pensadores da antiguidade (a filosofia dos Vedas, o budismo e a filosofia eleática), se manifesta, na época moderna, na doutrina kantiana da idealidade do tempo. Mas, segundo Spir, a doutrina de Kant — segundo a qual a sucessão não é senão a forma de percepção da realidade do sujeito cognoscente — "não é verdadeira, nem consequente"; é impossível tratar o tempo como o espaço, considerando-o como uma pura forma subjetiva, pois a realidade das ideias não pode ser colocada em questão e as ideias estão, evidentemente, submetidas ao movimento. ${ }^{28}$

Ante o modelo dualista kantiano e schopenhaueriano, Spir opõe um modelo de três níveis. Além da coisa em si, cuja existência se

26 "Quando Kant não pretende tomar o tempo por algo real, ele tem toda razão. Pois o tempo é uma mera abstração das sucessões reais e não pode, sem essas (quer dizer, como tempo vazio), ser representado. Mas contestar a realidade das sucessões dadas foi uma empreita estranha" (Spir, Afrikan. DW 1873, I, p. 265 nota, itálico acrescentado).

27 "Mas como a experiência de todas as épocas ensina — com exceção, talvez, de Heráclito e Hegel —, o espírito humano reluta em acreditar que o não-ser, a negação, tem alguma participação na essência própria, verdadeira, das coisas. Consequentemente, para a consciência dos homens, a mudança foi, desde sempre, um atributo e quase sinônimo da não-verdade" (Spir, Afrikan. DW 1873, I, p. 262). Cf. também o capítulo intitulado Prova de que a mudança não pertence à própria essência da coisa em Spir, DW 1873, I, p. 270 sq.

28 Spir, Afrikan. DW 1873, I, p. 263 sq. Além da idealidade do tempo, encontra-se também, no texto de Spir, uma refutação da aprioridade do tempo. Pode-se comparar, acerca desse tema, a estética transcendental de Kant (B46) com Spir DW. I, p. 13, 6 et 18, citado por Nietzsche no Nachlass/FP $35[56]$, KSA 11.537. 
D'Torio, P.

situa numa dimensão autêntica, não contraditória e atemporal, além das coisas tais como nós as vemos, que só existem na representação do sujeito, há também um outro nível ontológico intermediário em que os objetos existem realmente, mas não enquanto coisa em si. Eles existem de forma inautêntica e contraditória. É a esse nível que pertencem o sujeito cognoscente e suas representações.

De acordo com Kant e Schopenhauer, o tempo não é uma coisa que existe em si, ou que é inerente às coisas como uma determinação objetiva. Ele é somente a condição formal a priori dos fenômenos. De acordo com Spir, por outro lado, a mudança, que caracteriza o mundo fenomenal, possui uma existência objetiva e constitui uma forma de realidade. Trata-se, porém, de uma realidade que contém elementos estranhos à verdadeira essência das coisas — ela está submetida à mudança, à união do diverso, à falsidade (Unwahrheit), ao mal $^{29}$ — e que, por essa razão, e não somente devido à percepção do sujeito, se manifesta enquanto fenômeno. Eis o que escreve Spir no capítulo intitulado $O$ fenômeno e a aparência, e que Nietzsche parafraseia (sem, porém, se apropriar) no caderno P I 20.

Spir, DW 1873, I, p. 377

Se por conseguinte o conhecimento empírico contém, contudo, em sua própria essência fundamental algo de falso, se os objetos empíricos, contudo, tiverem de ser tomados como meras aparências, fenômenos, então aqui o elemento de falsidade repousaria nos próprios objetos empíricos e não meramente no próprio pensamento.
Nietzsche, Nachlass/FP 19[240], KSA 7.495.

O mundo é representação — mas não apenas nós somos causas de que ele apareça. Ele ainda é irreal de um outro ponto de vista.

Inversamente, Nietzsche assume como dado essencial, e como princípio fundamental, a realidade da mudança, sem, portanto, retirar o valor do mundo da experiência. A filosofia nietzschiana

29 Cf. as considerações recapitulativas ao fim do primeiro tomo, p.452 sq., comentadas infra p. 50.

26 | Cad. Nietzsche, Guarulhos/Porto Seguro, v.42, n.2, p. 11-60, maio/agosto, 2021. 
dos anos subsequentes tentará resolver a separação entre numenal e fenomenal, demonstrando que o mundo numenal (acessível somente ao pensamento puro), e não o mundo fenomenal, é uma contradição nascida de uma ilusão da razão. Em suas lições sobre os filósofos pré-platônicos, Nietzsche já utiliza Spir contra a doutrina kantiana e schopenhaueriana da idealidade transcendental do tempo; mas ele novamente está bem longe de seguir o caminho da recusa do mundo sensível enquanto submetido ao movimento. As personagens que mais fascinam Nietzsche nesse período são Heráclito e Demócrito, ambas ligadas à realidade do tempo e da mudança, e à afirmação do mundo do vir-a-ser governado pela lei e pelo jogo: "Com Heráclito é entoada a crença incondicionada no movimento: que todo movimento pressupõe um antagonismo: que a luta é o pai das coisas." ${ }^{30} \mathrm{O}$ texto sobre A filosofia na época trágica dos gregos é incompleto, mas a série de cursos universitários sobre os Filósofos pré-platônicos continua com Leucipo e Demócrito, a quem foram atribuídas as opiniões dos adversários dos eleatas, e a quem foi confiada a defesa da realidade do movimento com a mesma argumentação que Spir utilizou contra Kant: a realidade do movimento do pensamento. ${ }^{31}$

O sistema de Demócrito é julgado por Nietzsche como o mais consequente de todos os sistemas da antiguidade, uma expressão do ultrapassamento da fase mítica do pensamento grego, prometido para um futuro mais fecundo. Trata-se de um sistema materialista dominado por uma rigorosa necessidade em que o curso da natureza jamais é interrompido por intervenções sobrenaturais, e que representa,

30 Os filósofos pré-platônicos, KGW, II/4, p. 334 . Cf. a carta a Rohde do dia 9 de dezembro de 1868, KSB 2. 348-353: "A mim, a imagem de Demócrito agrada muito" e Nachlass/FP 23[17], KSA 7.546, no qual Demócrito é definido como "o homem mais livre".

31 "O ponto de partida de Demócrito e Leucipo são as sentenças dos eleatas. Demócrito parte somente da realidade do movimento, pois, de fato, o pensamento é um movimento. Esse é, com efeito, o ponto de ataque: "há um movimento: pois eu penso: e o pensamento possui realidade" " (v. Die vorplatonischen Philosophen, p. 331). Cf. também Nachlass/FP 23[39], KSA 7. 556 e 557 (fragmento preparatório do curso, onde pode-se ler, entre as hipóteses fundamentais atribuídas a Demócrito: "Há movimento, logo, espaço vazio, logo, não-ser. O pensamento é movimento". 
D'Torio, P.

assim, uma hipótese diretamente utilizável pela ciência. Além disso, o sistema de Demócrito é a expressão de um grande pensamento que tem a força de conduzir o mundo ordenado e finalista, povoado por incontáveis qualidades, a uma força ínfima, com uma audácia que Nietzsche compara à célebre frase de Kant em História natural do céu]: "Dê-me somente a matéria e eu disso farei um mundo". ${ }^{32}$

Ao fim do parágrafo sobre Demócrito, Nietzsche retoma, contudo, as contradições que acometem a doutrina materialista quando, partindo do mais simples estado da matéria ao mais complexo, à sensação, ele se dá conta de que essa última deveria ser já pressuposta desde o início da investigação. Com efeito, a representação da matéria, que o materialismo toma como fundamento, não é algo dado, mas o produto complexo de nosso aparelho cognitivo.

É uma tremenda petitio principii: mostra-se subitamente a última ligação enquanto ponto de partida, sobre a qual a primeira ligação da corrente já está vinculada. - Por essa razão, comparam-se os materialistas ao Barão von Münchhausen que, debatendo-se na água montado em seu cavalo, levanta-o com suas pernas e levanta a si mesmo pela ponta de sua peruca puxada para frente. $\mathrm{O}$ absurdo consiste nisto que ele parte do objetivo: enquanto, na verdade, todo objetivo é condicionado de várias formas pelo sujeito cognoscente, que, portanto, desaparece sem o sujeito. ${ }^{33}$

Mas, bem longe de se dar por satisfeito com essa crítica, Nietzsche conclui que mesmo que o materialismo não represente a verdade definitiva sobre as coisas, é uma "hipótese válida de verdade relativa", uma hipótese que concerne nosso mundo, com cuja construção estamos constantemente ocupados.

32 Die vorplatonischen Philosophen, p. 334.

33 Op. cit., p. 339. A citação é literal de $O$ mundo como vontade e representação de Arthur Schopenhauer (cf. tomo I, § 7, p. 32-33) e essa referência, ainda que não tenha sido explicitada por Nietzsche, demonstra o caráter sempre contemporâneo de suas reflexões sobre a Grécia.

28 | Cad. Nietzsche, Guarulhos/Porto Seguro, v.42, n.2, p. 11-60, maio/agosto, 2021. 


\title{
2. A leitura de 1877
}

\author{
Mas Heráclito teve eternamente razão \\ em dizer que o ser é uma fição vazia. \\ O mundo "aparente" é o único: \\ $O$ "mundo verdadeiro" \\ foi mendazmente colocado aí \\ GD/CI, A razão na filosofia, 2
}

1. Quatro anos após as reflexões ontológicas a respeito da realidade e transformação extraídas de Spir, Nietzsche retorna às suas páginas, interessando-se por um outro conjunto específico de problemas. A filosofia de Spir, com efeito, parte de uma análise das relações entre a verdadeira essência das coisas, o incondicionado, e o mundo do vir-a-ser, o condicionado. Contudo, uma ciência do incondicionado é, para Spir, o apanágio exclusivo de uma filosofia dogmática, isto é, de uma filosofia que não se preocupa primordialmente com uma investigação da natureza, das leis e os limites de nossa faculdade cognitiva. Com efeito, a filosofia crítica, cujo livro de Spir pensa ser uma reforma, conduz à demonstração da impossibilidade da metafísica enquanto ciência do incondicionado. Porém, se de um lado Spir exprime por vezes intolerância ante as hipóteses metafísicas, que procuram deduzir o conceito de incondicionado a partir de caráteres do condicionado,${ }^{34}$ de outro ele não renuncia à possibilidade de uma ciência do conceito de incondicionado, necessária para alcançar um nível superior de consideração da realidade (cf. SPIR, Afrikan. DW, I, p. 2 e 4$)$.

34Cf. esses dois parágrafos da introdução, que no exemplar de Nietzsche são marcados por duas linhas na margem: "Simplesmente não se quer entender que o estabelecimento de hipóteses sobre aquilo que se encontra para além de toda experiência é uma empreitada sem sentido " (SPIR, Afrikan. DW, I, p. 2) ; “Eu devo confessar que eu considero a orientação metafísica na filosofia como um tipo de doença eSpiritual que não pode ser erradicada através de argumentos" (Idem, p. 4). 
D'Torio, P.

Segundo Spir, o incondicionado, que coincide substancialmente com a coisa em si e com o absoluto, é o que possui em si a razão de sua existência, assim que todas as coisas que o sujeito conhece no mundo da experiência são condicionadas enquanto submetidas às estruturas que tornam a experiência possível. O condicionado, por sua natureza mesma, não pode existir sem o incondicionado, o vira-ser não pode existir sem o ser. Mas — e esse é o eixo da filosofia de Spir - a relação entre condicionado e incondicionado não pode ser de natureza causal.

Aplicando esse simples princípio lógico (a saber, que o incondicionado não pode condicionar), chega-se à impossibilidade de conceber a metafísica como explicação do mundo. Não é possível interpretar a natureza a partir do fenomenal para alcançar o absoluto, pois a aparência não pode ser manifestação da essência.

E no que concerne ainda à explicação metafísica das coisas, a derivação do condicionado a partir do incondicionado, reconhecemos na mesma o erro primordial e fundamental que deu a todo desenvolvimento do pensamento filosófico uma falsa (dogmática) orientação. A busca pela explicação metafísica das coisas é o mesmo que a busca pela quadratura do círculo, pelo perpetuum mobile e pela transmutação da matéria. (SPIR, Afrikan. DW, II, p. 290) ${ }^{35}$

Nietzsche estima a luta de Spir contra essa suposição fundamental da filosofia metafísica, e se serve das observações dele para opô-las ao conceito de metafísica como decifração da experiência, tal como enuncia Schopenhauer nos Suplementos a $O$ mundo como vontade e representação.

Schopenhauer escreve que, após Kant, a possibilidade de uma metafísica dogmática desapareceu, deixando aberta, contudo, a possibilidade de uma metafísica imanente, uma ciência da experiência em geral, fundada sobre a experiência, que se configura enquanto decifração do fenômeno e que fala das coisas em si somente em

35 Há uma linha na margem no exemplar de Nietzsche.

30 | Cad. Nietzsche, Guarulhos/Porto Seguro, v.42, n.2, p. 11-60, maio/agosto, 2021. 
relação com esta última. A experiência em sua totalidade aparece para Schopenhauer como uma escrita oculta que a filosofia tem o dever de decifrar ao propor hipóteses explicativas, cuja validade é obtida a partir do grau de coerência que elas introduzem nos fenômenos: "Quando se encontra um escrito cujo alfabeto é desconhecido, continua-se tentando interpretar até atingir uma hipótese sobre o significado das letras pelas quais elas formam palavras compreensíveis e períodos conectados" (SCHOPENHAUER, Arthur, Die Welt, tomo II, pp. 202-5).

Naturalmente, para essa concepção de metafísica, é preciso pressupor que a experiência é uma manifestação da coisa em si.

Eu admito inteiramente a doutrina de Kant de que o mundo da experiência é um mero fenômeno e que o conhecimento a priori só vale em relação àquele: mas eu acrescento que, precisamente enquanto fenômeno, é a manifestação do que aparece, e eu chamo o que está com ele coisa em si. (ivi., p. 204).

Spir se refere a essa passagem para destacar a inconcebível ingenuidade de Schopenhauer, que condescendente com a suposição fundamental de todo metafísico, busca partir do condicionado para o incondicionado ${ }^{36}$. Mas, para Spir, o incondicionado não pode condicionar e, logo, na experiência não é a coisa em si que se manifesta, mas o fenômeno que aparece a ele mesmo.

Através de nossas investigações, fomos levados à proposição, a qual parecia tão absurda a Herbart (All. Met. I, p. 285), a saber, que ofenômeno aparece a si mesmo. Mas a quem poderia aparecer a não ser para si mesmo? Ele se decompõe em dois fatores, o sujeito e objeto do conhecimento, que existem somente em sua relação recíproca. Mas precisamente essa decomposição e essa relatividade são estranhas à coisa ou o real em si. Ele não pode ser apreendido nem como sujeito, nem como objeto do conhecimento, e de sua essência não se pode derivar a natureza do cognoscível. É uma

36 "A pressuposição fundamental dos metafísicos é a de que o incondicionado contém a razão suficiente do condicionado; por isso eles tomam por sua principal tarefa deduzir o condicionado do incondicionado" (SPIR, Afrikan. DW I, p. 293. Em seu exemplar, Nietzsche marcou esse parágrafo com um traço na margem). 
D’Torio, P.

incompreensível ingenuidade quando Schopenhauer (W. $a$. W. $u$. V. II, p. 204) pretende fazer do fenômeno "a manifestação disso que aparece, da coisa em si", para disso fazer com que o fim da metafísica seja interpretar a coisa em si desde o fenômeno. Chama-se com razão o objeto empírico de fenômenos (Phänomena); fenômenos (Erscheinungen), porém, não porque neles aparece (erschiene) um númeno, mas porque eles aparecem a nós mesmos, enquanto o númeno não o faz. (SPIR, Afrikan. DW, I, p. 311). ${ }^{37}$

Nietzsche utiliza contra a metafísica de Schopenhauer essas observações de Spir, mas, num fragmento de 1877, e num importante aforismo de Humano, demasiado humano, ele convida a um ultrapassamento da ciência do incondicionado, e da ciência do conceito de incondicionado, em nome de uma história da gênese do pensamento.

Enquanto Schopenhauer alega sobre o mundo fenomenal que, em sua escritura, ele fornece conhecimento da essência das coisas em si mesmas, os lógicos mais rigorosos negaram toda ligação possível entre o incondicionado, o mundo metafísico, e o mundo que conhecemos: de tal forma que não é a coisa em si que aparece no fenômeno. (Nachlass/FP 23[125], KSA 8. 447). Mas de ambos os lados se omite a possibilidade de que essa pintura aquilo que para nós, homens, se chama vida e experiência — gradualmente veio a ser, está em pleno vir-a-ser, e por isso não deve ser considerada uma grandeza fixa, da qual se pudesse tirar ou recusar uma dedução sobre o autor (a razão suficiente). Assim, é por olharmos o mundo, há milhares de anos, com pretensões morais, estéticas, religiosas, com cega inclinação, paixão ou medo, nos regalado nos maus hábitos do pensamento ilógico, que este mundo gradualmente se tornou estranhamente variegado, terrível, profundo de significado, cheio de alma, adquirindo cores - mas nós fomos os coloristas: é o intelecto humano que fez aparecer o fenômeno e que introduziu nas coisas as suas interpretações fundamentais errôneas. Tarde, bem tarde - ele cai em si: agora o mundo da experiência e a coisa em si lhe parecem tão extraordinariamente diferentes e separados, que ele rejeita a conclusão sobre esta a partir daquele [...]. Com todas essas

37 Há linhas na margem do exemplar de Nietzsche de Pensamento e realidade; ademais, ao lado do último parágrafo, Nietzsche escreveu "gut" (bom). No que concerne à relação do mundo com o incondicionado, cf. também o capítulo homônimo, Spir, Afrikan. DW, I, p. 279 sq.

32 | Cad. Nietzsche, Guarulhos/Porto Seguro, v.42, n.2, p. 11-60, maio/agosto, 2021. 
interpretações, o constante e árduo processo da ciência, que celebrará seu maior triunfo numa história da gênese do pensamento, completar-se-á de forma decisiva, e cujo resultado talvez possa redundar nesta proposição: o que atualmente chamamos mundo é o resultado de uma profusão de erros e fantasias que surgiram gradualmente na evolução conjunta dos seres orgânicos e cresceram juntos, e que agora herdamos como o tesouro acumulado do passado - como tesouro: pois o valor de nossa humanidade nele reside. (MA I/HH I 16, KSA 2.36 e 37).

Com o tom sereno e nobre que caracteriza o pathos de Humano, demasiado humano, Nietzsche arruína toda a tradição metafísica, não em nome de uma filosofia "mais profunda", que saberia com mais propriedade se colocar à escuta do ser, mas pela vontade de fazer uma história natural dos processos cognitivos, indicando na história da gênese do pensamento a origem e a solução dos problemas metafísicos.

Desse modo, Nietzsche define claramente o horizonte para o qual se dirige sua filosofia nos anos seguintes, e retira uma primeira conclusão importante: a percepção do mundo é possível graças a uma série de "hábitos da sensação" herdados. Alguns remontam à pré-história da humanidade, ou mesmo ao nascimento dos primeiros seres orgânicos; outros são recentes e caracterizam uma forma particular de cultura. A reflexão teórica de Nietzsche desemboca num construtivismo radical no qual ele explorará as consequências sobre os modos de perceber e sentir o mundo. Ele se comprometerá com uma análise de diferentes níveis categoriais, da resistência deles à mudança; denunciará os erros incorporados na língua e nas estruturas da razão e, por fim, procurará elaborar filosofemas mais aptos a exprimir o caráter interpretativo do vir-a-ser e a valorizar o caráter transitório de um mundo no qual não existem essências ou estruturas ontológicas desprovidas de vir-a-ser.

Nessas reflexões, a ambivalência da atitude de Nietzsche ante a filosofia de Spir reaparece. Não somente a análise transcendental de Spir facilita a refutação da filosofia dogmática, mas ela também fornece a Nietzsche uma discussão aprofundada dos conceitos fundamentais como 
D’Torio, P.

incondicionado, substância, leis lógicas, que ele considera efetivamente operantes no cerne de nosso processo cognitivo, mesmo se ele os pense não como verdades eternas e $a$ priori, mas como erros que nasceram no curso da história do pensamento; eles são extraídos de forma grosseira da experiência em épocas primitivas do desenvolvimento dos seres orgânicos. Um de seus erros originais é a crença no incondicionado, e um outro é aquilo que Spir chama de "lei da substância", a qual Nietzsche, no aforismo 18 de Menschliches, Allzumenschliches, indica a gênese.

Questões fundamentais da metafísica. Uma vez escrita a história da gênese do pensamento, a seguinte proposição de um eminente lógico também se encontrará sob uma nova luz: "A originária e geral lei do sujeito cognoscente consiste na necessidade interior de conhecer todo objeto em si, em sua própria essência enquanto idêntico consigo mesmo, portanto, existindo por si mesmo e, fundamentalmente, sempre igual e imutável, em suma, enquanto uma substância (MA I/HH I 18, KSA 2. 38 e 39).

Naturalmente o "eminente lógico" (ausgezeichnete Logiker) é Spir, que consagrou alguns capítulos de sua obra para a exposição da "verdadeira teoria de nosso conhecimento dos corpos". O núcleo dessa teoria é precisamente a ação da lei da substância, uma lei interior do sujeito congnoscente, derivada do conceito de incondicionado, e que permite ao sujeito ordenar o caos indistinto das sensações num modelo de objetos situados no espaço ${ }^{38}$.

Nietzsche não coloca em discussão a existência dessa lei, mas ele contesta o caráter inato e "apriorístico" ("essa lei, que é chamada aqui 'originária', também veio-a-ser"), considerando-a uma herança da evolução e uma condição de existência de seres orgânicos. Do período dos organismos inferiores, o homem herdou a crença de que existem coisas idênticas, substâncias incondicionadas, ações isoladas de outros acontecimentos, isto é, ações de uma vontade livre; e a filosofia metafísica não passa de uma reflexão inesgotável e inconsciente sobre

38 Nietzsche, no HH I/MA I 18, cita Spir, DW, II, p. 177; mas, para obter um desenvolvimento mais exaustivo da lei da substância, cf. Spir, Afrikan. DW, I, p. 120 sq. e p. 192; DW, II, p. 87 e p. 68-9:

34 | Cad. Nietzsche, Guarulhos/Porto Seguro, v.42, n.2, p. 11-60, maio/agosto, 2021. 
esses erros originais: "Uma vez que que a metafísica se empenhou principalmente com a substância e liberdade da vontade, pode-se designá-la como a ciência que lida com os erros fundamentais do homem como se fossem verdades fundamentais." (MA I/HH I 18, KSA 2. 40).

A metafísica enquanto ciência do incondicionado é desprovida de sentido; a metafísica enquanto ciência do conceito de incondicionado pode fornecer um material útil para a história da gênese do pensamento, sob a condição de não substancializar os conceitos, compreendendo que "incondicionado", "substância", etc., são invenções que viabilizaram a evolução e sobrevivência dos seres orgânicos.

2. Em Humano, demasiado humano encontramos uma outra referência importante a Spir no interior de uma crítica das nostalgias religiosas na música, na arte figurativa, na filosofia, na crítica histórica e mesmo na lógica.

Numa consideração que fecha o capítulo consagrado à relação entre fenômeno e aparência - logo após a passagem citada acima, na qual foi confirmada a impossibilidade de chegar ao incondicionado pelo deciframento do fenômeno - Spir emite a audaciosa afirmação segundo a qual é a esfera da poesia, da moralidade, da religiosidade, e não do conhecimento, que se permite o contato com a essência do mundo, verdadeira, autêntica e incondicionada. Arte, moral e religião, segundo Spir, nos fazem tocar o em-si, "como se existisse um saber particular que escaparia àqueles que aprendem alguma coisa". ${ }^{39}$

Há, com efeito, intrusão ou indicação da coisa em si, quer dizer, da verdadeira e mais elevada essência das coisas, no mundo da experiência; mas não de natureza física, e sim estética e moral. Eles são, no mundo exterior, a beleza, no mundo interior, a poesia, a moralidade e a religiosidade. Estes não são o produto da ação da coisa em si, do númeno, mas do fato que o mundo da experiência, por um lado de sua essência, estar relacionado com o númeno ou o incondicionado, possuir uma parte da natureza elevada das coisas, portar algo da nobre substância, precisamente por ser deste fenômeno.

39Za/ZA, "Dos poetas", KSA 4. 164.

Cad. Nietzsche, Guarulhos/Porto Seguro, v.42, n.2, p. 11-60, maio/agosto, 2021.| 35 
D'Torio, P.

Nessa conexão não há nada de físico, nada da coerção que faz com que uma coisa produza seu efeito. Essa conexão é de natureza suprafísica e abre o reino da liberdade (Spir, Afrikan. DW, I, p. 312). ${ }^{40}$

Nietzsche critica essas posições em alguns aforismos importantes do primeiro volume de Humano, demasiado humano, nos quais, citando A origem dos sentimentos morais de Paul Rée, defende que "o homem moral não está mais próximo do mundo moral (metafísico) que o homem físico" (MA I/HH I 37, KSA 2.61). Ele afirma ainda que "com a religião, arte e moral nós não tocamos a 'essência do mundo em si'; nós estamos no domínio da representação, nenhuma 'intuição' (Ahnung) pode nos carregar adiante" (MA I/HH I 10, KSA 2.30), e não é senão pela ciência que o homem se aproxima da verdadeira essência do mundo e do seu conhecimento, "ainda que ele acredite fazer melhor com suas religiões e suas artes" (MA I/HH I 29, KSA 2.49).

Em particular, num aforismo consagrado às nostalgias religiosas, e que coloca em causa Schopenhauer, Wagner, Renan e D.F. Strauß, Nietzsche se refere explicitamente a Spir quando ele escreve:

A filosofia científica deve estar alerta para não introduzir erros com base em tal necessidade (religiosa) - uma necessidade que veio a ser e que, portanto, também passará -: mesmo os lógicos falam de "pressentimentos" da verdade na moral e na arte (por exemplo, a intuição que "a essência das coisas é una"): o que lhes deveria ser proibido. (MA I/HH I 131, KSA 2.124).

A crítica que Nietzsche impõe às teorizações intuicionistas é severa. Entre as verdades científicas e os presságios de verdade que se encontram na arte, na moral, na religião, existe uma profunda diferença metodológica. O pressentimento não é uma forma de conhecimento, não passa da vontade de crer que uma coisa pode ser verdadeira: "A fome não demonstra que há uma alimentação apta a acalmá-la, mas que ela deseja a alimentação". Se Spir considera que o fim da filosofia

40 Nietzsche, no seu exemplar, traçou uma linha e um ponto de exclamação ao lado dessas palavras.

36 | Cad. Nietzsche, Guarulhos/Porto Seguro, v.42, n.2, p. 11-60, maio/agosto, 2021. 
é atingir a certeza, Nietzsche replica: "a intuição (die «Ahnung») não nos faz avançar no terreno da certeza" (MA I/HH I 131, KSA 2.124).

\title{
3. A leitura de 1881
}

\author{
Parmênides disse: "não se pensa o que não existe" \\ estamos em outro fim e dizemos: "o que pode ser pensado \\ deve ser certamente ficção"
} Nachlass/FP 14[148] da primavera de 1888.

1. Nietzsche se volta uma terceira vez sobre as páginas de Afrikan Spir em 1881. Ao fim do primeiro volume de Pensamento e realidade, Spir tira as conclusões de sua investigação, meditando novamente sobre a relação entre condicionado e incondicionado, e explicitando o resultado problemático de sua filosofia.

O fenômeno, como nós já dissemos, não possuindo existência própria, tem necessidade do númeno; mas o incondicionado, por definição, não pode ser considerado razão suficiente do fenômeno. Chega-se, assim, a uma antinomia que confirma o fracasso, não só da metafísica, mas também de toda filosofia que desejava explicar a essência do mundo. Spir escreve:

Se, sobretudo, o condicionado deve ter, enquanto tal, uma condição, então esta deve necessariamente ser incondicionada. Que o condicionado, enquanto tal, não pode ter condições; que o incondicionado nunca pode ser pensado como condição ou causa; que uma causa ou condição nunca podem ser pensadas como incondicionadas; nisso consiste a antinomia fundamental". (SPIR, Afrikan. DW I, p. 378). ${ }^{41}$

Em outras palavras, se as coisas da experiência não possuem ser próprio, e se o "ser verdadeiramente próprio" das coisas não

41 Encontram-se, no exemplar de Nietzsche, também três traços ao lado das duas últimas linhas, a partir de: "Causa ou". 
D’Torio, P.

pode ser considerado como razão suficiente delas, como explicar a existência do mundo sensível? "Ser condicionado" significa conter elementos que não pertencem à natureza verdadeiramente própria das coisas. Mas de onde vêm "os elementos da realidade dada que são estranhos à natureza verdadeira das coisas?" A antinomia é insolucionável. A mesma razão que torna necessária uma explicação do mundo prova, segundo Spir, que essa explicação é impossível.

Spir, DW I, p. 379-80

Ou seja, aqueles elementos na realidade dada, que são estranhos à verdadeira essência das coisas e do efetivo, não podem evidentemente provir dela. Como estranhos, eles têm de ser acrescidos a ela. Mas já que fora do efetivo não existe nada de onde algo poderia provir ou surgir, então é simplesmente impossível compreender de onde vêm os elementos estranhos. Por conseguinte, podemos tocar aqui na antinomia que jaz na essência do condicionado. Tese e antítese têm aí um mesmíssimo fundamento. Precisamente porque a constituição do efetivo, dada e condicionada, é estranha a sua essência originária, ela tem de ter uma condição externa. Mas justamente porque ela é, em geral, em si estranha ao efetivo, ela não pode ter nem uma condição externa nem outra qualquer, já que fora do efetivo nada existe. Portanto esse mesmo fundamento, que torna necessária uma explicação do mundo, também mostra que essa explicação é impossível.
Nietzsche, Nachlass/

FP 11[329], KSA 9.569

A antinomia: "os elementos na realidade dada, que são estranhos à verdadeira essência das coisas, não podem provir desta, portanto têm de ser acrescidos".

“- Mas de onde? Já que fora do verdadeiro efetivo não existe nada"

"- Portanto, uma explicação do mundo é igualmente necessária e impossível"

Nietzsche, durante o verão de 1881, em Sils-Maria, retoma a antinomia de Spir — expressão de um modo de conceber a filosofia fundada sobre conceitos atemporais da razão pura e que utiliza esses últimos para julgar (e condenar) o vir-a-ser. Ele a resolve ao inverter a posição tradicional do problema. Não é o mundo sensível que nos engana e que é refutado pelas leis da lógica. Ao contrário, são as leis do pensamento (último produto de muitos erros assimilados e consolidados) que nos conduzem a uma série de contradições na análise da realidade, quer dizer, do mundo do vir-a-ser.

Com efeito, a solução de Nietzsche para o problema da relação entre pensamento e realidade é conduzida em nome de uma filosofia 
que atribui a verdadeira realidade ao vir-a-ser: o espírito humano, sua lógica, sua razão, "vieram a ser". Nossas sensações confirmam a realidade da mudança, e se, por conseguinte, a razão interpretar falsamente o material sensorial, e acreditar na permanência, na substância, na identidade, etc., se ela multiplicar sem necessidade os entes, nós não podemos senão invocar a navalha de Occam e afinar nossa razão, sem sermos autorizados, ainda assim, a desprezar nossos sentidos "enganadores". ${ }^{42}$

Assim, para descrever a relação entre pensamento e realidade, e resolver a antinomia de Spir, Nietzsche propõe, ao invés da dedução lógica, um tipo de epistemologia evolutiva. Com efeito, eis o resultado do fragmento que contém o excerto de Spir:

Eis como eu soluciono isso: a verdadeira essência das coisas é uma fabulação do ser que representa, sem o qual não haveria como representar. Esses elementos na efetividade dada, estranhas a esta "verdadeira essência" fabulada, são propriedades do ser, elas não são acrescentadas. Mas também é preciso que tenha se originado o ser representante, cuja existência está vinculada à crença errônea, se, de outro lado, suas propriedades (aquelas da modificação, da relatividade) são próprias ao esse: ao mesmo tempo precisa representar $e$ acreditar que o idêntico a si mesmo e o permanente surgiram. - quero dizer, que todo orgânico já pressupõe a representação (Nachlass/FP 11[329], KSA 9.569).

Mas, segundo Spir, o mundo empírico não pode possuir realidade própria, pois ele é afetado por quatro características que não podem pertencer à verdadeira realidade das coisas: 1) a mudança, 2) a relatividade da união do diverso segundo certas leis, 3) a falsidade que se encontra no conhecimento da realidade, 4) o mal e a imperfeição das coisas empíricas (cf. DW I, p. 381).

42 Cf. a última formulação recapitulativa do Crepúsculo dos ídolos: "[Os sentidos] não mentem. O que fazemos com seu testemunho introduz a mentira, por exemplo, a mentira da unidade, a mentira da coisidade, da substância, da duração... A "razão" é a causa que nos faz falsear o testemunho dos sentidos. Na medida em que os sentidos mostram o vir-a-ser, a passagem, a transformação, eles não mentem...” (GD, A “razão" na filosofia, 2, KSA 6.75). 
Nós já falamos muito do movimento (cf. particularmente p. 29 e a nota 28). No que concerne ao segundo ponto, Spir afirma que a pluralidade e a união condicionada do diverso segundo certas leis, ainda que não sejam contraditórias, não são incondicionadas e não podem, portanto, pertencer à essência das coisas ${ }^{43}$. Sobre a falsidade induzida pela estrutura do conhecimento, e sobre o mal, eis o que escreve Spir, com a paráfrase e comentário que Nietzsche fez no caderno M III 1.

Spir, DW I, p. 382

No que diz respeito à falsidade no conhecimento, foi mostrado que o conhecimento em geral, que pressupõe a separação da realidade entre um sujeito e um objeto, é estranho à verdadeira essência mesma, isto é, ao real em si. Também apontei várias vezes que se o conhecimento pertencesse à própria essência das coisas, uma falsidade nele não seria simplesmente possível. Que a existência da falsidade não pode ser deduzida da própria, verdadeira essência das coisas, é algo que qualquer um verá sem dificuldade. ${ }^{44}$

No que diz respeito enfim ao mal e à imperfeição, aquela tentativa de deduzi-la da natureza própria, normal, das coisas, é justamente um desvario. Pois, como já mostrei acima, a dor e o mal trazem em si mesmos, imediatamente, $o$ atestado de que eles não pertencem à essência das coisas, que encerram uma anomalia, são algo que não deveria existir, que nega e condena a si mesmo].
Nietzsche, Nachlass/FP 11[321], KSA $9.566-567$

A falsidade tem de ser dedutível da "verdadeira e própria essência" das coisas: a separação entre sujeito e objeto tem de corresponder ao fato. Não o conhecimento, mas o erro, pertence à essência das coisas. A crença no incondicionado tem de ser dedutível da essência do esse [ser], do ser condicionado em geral!

O mal e a dor pertencem àquilo que é efetivo: mas não como propriedade duradoura do esse [ser]. Pois o mal e a dor são apenas consequências do representar, e o representar é uma propriedade eterna e universal de todo ser, se existirem em geral propriedades eternas, se o vir-a-ser não encerre tudo o que é igual e permanente, a não ser na forma de erro e aparência, enquanto o próprio representar não é um processo sem igualdade e permanência? - $\mathrm{O}$ erro surgiu como propriedade do ser? Errar é então um constante vir-a-ser e mudança?

43 Cf. o capítulo: $O$ real é em si um (Spir, Afrikan. DW, I, p. 295 s.).

44. Spir se remete a uma passagem contida no capítulo A relação do mundo com o incondicionado (DW I, p. 292).

40 | Cad. Nietzsche, Guarulhos/Porto Seguro, v.42, n.2, p. 11-60, maio/agosto, 2021. 
A estrutura da realidade elaborada por Nietzsche nessas notas é completamente oposta àquela de Pensamento e realidade, que parece até mesmo lhe servir de modelo negativo. Se, segundo Spir, a verdadeira essência das coisas é incondicionada, imutável, única, perfeita e estranha ao processo de representação e ao erro, e se o mundo da experiência é produzido por uma (inexplicável) intervenção de elementos estranhos, por outro lado o esse do qual fala Nietzsche nos fragmentos póstumos de 1881, o ser que representa as coisas, é o exato contrário. Ele é condicionado, em mudança, ele possui o erro como condição de existência, pois, para viver, ele necessita inventar um mundo de substâncias e de coisas idênticas, um mundo de essências imutáveis. Isso que Spir chama de "eigene wahre Wesen der Dinge" (verdadeira e própria essência das coisas) é, segundo Nietzsche, o mundo inventado pelo ser que representa as coisas, por aquilo que Spir considerava como um elemento estranho à verdadeira essência das coisas e que, para Nietzsche, é, pelo contrário, a forma mais geral da realidade.

É um Nietzsche fortemente ligado ao texto de Spir que escreve os fragmentos póstumos 11[162,324,325, 330], nos quais é conhecida a teoria do ser que possui representações como caráter geral da realidade, uma teoria que conduzirá à ideia ulterior da vontade de potência enquanto princípio ontológico.

Spir baseia toda sua obra sobre a certeza imediata que se obtém a partir dos dados da consciência, e sobre o conceito de incondicionado enquanto lei fundamental do pensamento. ${ }^{45} \mathrm{~A}$ teoria do ser que representa as coisas nos fragmentos póstumos de 1881 desenvolvese a partir desses dois pontos fundamentais do sistema spiriano.

No que concerne aos dados do conhecimento, Spir distingue a existência da representação da existência do conteúdo representado e, referindo-se ao cogito cartesiano, of erece a seguinte interpretação:

45 “A visão das coisas oferecida no presente trabalho tem como ponto de partida e fundamento a dupla certeza imediata, que nos apresenta, por um lado, os fatos da consciência mesma e, por outro lado, a lei fundamental do pensamento" (SPIR, Afrikan. DW, I, p. 31). 
D’Torio, P.

A proposição cartesiana Cogito, ergo sum, expressa de modo geral e preciso, deve ser lida da seguinte forma: tudo que eu encontro em minha consciência é, enquanto simples fato da consciência, imediatamente certo. Duvidoso é se esse conteúdo se conforma com algo exterior, mas o conteúdo dado da consciência mesma está fora de toda dúvida. No conteúdo de nossa consciência temos, portanto, toda certeza imediata de natureza atual. (Spir, Afrikan. DW, I, p. 27-28). ${ }^{46}$

A certeza extraída do conteúdo da consciência permite a Spir fundar a realidade do mundo do fenômeno, esse nível ontológico intermediário, possuindo uma forma inautêntica de realidade, mas diferindo da pura aparência. Pelo contrário, em 1881, Nietzsche — que em 1885 discutirá em detalhes o tipo de certeza que é possível obter a partir do cogito cartesiano - considera o processo de representação como nossa única forma de realidade certa (apesar de não imediatamente certa).

\section{Certeza fundamental.}

Eu represento, logo, há um ser" cogito, ergo est. - Que eu seja esse ser que representa, que representar seja uma atividade do eu, não é certo: tampouco tudo o que eu represento. - O único ser que conhecemos é o ser que representa. (Nachlass/FP 11[330], KSA 9.569).

O ser que representa é certo, nossa única certeza: o que isso precisa representar e como isso precisa representar, é o problema. Que o ser representa, não é problema, é justamente o fato: se há um outro ser, além daquele que representa, se a representação não pertence à propriedade do ser, é um problema. (Nachlass/FP 11[325], KSA 9.568).

O conceito de incondicionado, segundo pilar do sistema de Spir, fornece uma certeza de natureza lógica que guia a percepção que o sujeito possui do mundo.

A razão da certeza na conclusão retirada das coisas empíricas é a certeza originária de que, apesar de se apresentar sempre como uma novidade aos

46 Nietzsche faz um traço ao lado do texto no seu exemplar.

42 | Cad. Nietzsche, Guarulhos/Porto Seguro, v.42, n.2, p. 11-60, maio/agosto, 2021. 
nossos sentidos, e apesar de toda mudança, que ocorre para a percepção, há, contudo, nos fenômenos, algo que permanece sempre o mesmo, que em todas as modificações particulares sua natureza permanece, em geral, sempre igual a si mesma e que, assim, há na natureza casos idênticos. Essa certeza originária dos casos idênticos é um entendimento geral a priori, que confere segurança às induções, oferecendo-lhes, com isso, um valor e um caráter científico". (SPIR, Afrikan. DW, I, p. 102). ${ }^{47}$

Se o pensamento em sua função não fosse determinado por leis lógicas, não haveria jamais falsidade no conhecimento. Inversamente, se o pensamento fosse unicamente submisso a leis físicas de associação de ideias, a verdade seria um puro acaso, e nós não teríamos nenhum meio de estabelecê-la com certeza. Logo, o critério da verdade no mundo empírico só pode derivar da ação de leis lógicas inatas ao sujeito (o princípio de identidade, a lei da substância) aplicadas às percepções imediatamente certas em nossa consciência, já unidas segundo as leis físicas de associação de ideias (cf. Spir, Afrikan. DW, I, p. 107).

Pelo contrário, segundo Nietzsche, os princípios lógicos não levam à verdade, mas são erros originários que permitiram o nascimento de uma forma de conhecimento. Reconhecer progressivamente os limites desse conhecimento nos permite obter uma representação menos deformada do real: "Sem a suposição de um gênero de ser oposto à realidade verdadeira, nós não teríamos nada para mensurar, comparar e reproduzir: o conhecimento pressupõe o erro" (Nachlass/ FP 11[325], KSA 9. 567).

Todo conhecimento é necessariamente falso, pois ele se desenvolve sobre uma base de erros originários, sobre a crença no sujeito, na estabilidade do objeto, na existência de coisas idênticas ou de acontecimentos reproduzíveis; de outra parte, sem essa falsificação, o conhecimento não poderia nascer. $\mathrm{O}$ processo de representação é construído sobre o erro, mas permite estabelecer gradações de erros e, portanto, gradações de verdade. Enquanto Spir se pergunta pela

47 As expressões sublinhadas correspondem àquelas do exemplar de Nietzsche. Há também traços na margem.

Cad. Nietzsche, Guarulhos/Porto Seguro, v.42, n.2, p. 11-60, maio/agosto, 2021.| 43 
D'Torio, P.

proveniência dos elementos estranhos à realidade verdadeira que se manifestam no fenômeno, e como o erro foi possível, Nietzsche escrevia: "A questão não é saber como o erro é possível, mas: como um gênero de verdade é somente possível apesar da falsidade fundamental no conhecimento?"48

Descrevendo exatamente o processo da representação, que, segundo Nietzsche, é a única forma do ser que nos é acessível, nós obtemos os predicados do ser em geral e nós nos damos conta de que o processo de representação não pode subsistir a não ser pelo desconhecimento radical da estrutura do ser. Com efeito, o caráter principal do ser que representa as coisas é a mudança. Não se trata somente da sucessão de imagens e pensamentos no espelho da consciência que está continuamente em movimento: o espelho mesmo está imerso na história; ele se modifica segundo as imagens que ele reflete, ele aumenta, escurece, ele jamais permanece idêntico a si mesmo. Porém, o processo de representação só pode ocorrer quando se crê na existência de um sujeito idêntico a si mesmo e de um objeto substancial dotado de qualidades duráveis: "Em suma, isso que o pensamento abrange como o real, que deve apreender, pode muito bem ser o contrário do existente" (Nachlass/FP 11[330], KSA 9.570).

\section{A leitura de 1885}

Este é o maior erro que foi cometido, a autêntica fatalidade do erro na Terra: acreditava-se ter um critério de realidade nas formas da razão, enquanto se tinha, para se assenhorear da realidade, de desentender, de uma forma astuta, a realidade... Nachlass/FP 14[153] da primavera de 1888.

48 Nachlass/FP 11[325], KSA 9.568. Wie ist Unwahrheit möglich? [Como a falsidade é possível?] é o título do primeiro parágrafo da primeira parte, livro I, capítulo III, de Pensamento e realidade (Spir, Afrikan. DW, I, p. 81).

44 | Cad. Nietzsche, Guarulhos/Porto Seguro, v.42, n.2, p. 11-60, maio/agosto, 2021. 
Em 1885 registra-se o último confronto direito que Nietzsche estabelece com o pensamento de Spir. De 16 de julho a 26 de setembro de 1885, Nietzsche fica mais uma vez em Sils-Maria, ocupando-se novamente com problemas gnoseológicos. Seu interlocutor privilegiado é sempre Spir, agora acompanhado por Gustav Teichmüller $(O$ mundo real e o aparente) e, provavelmente, Maximilian Drossbach (Sobre as causas aparentes e reais do processo no mundo). ${ }^{49}$ Durante esse período, Nietzsche relê também o caderno que continha as reflexões gnoseológicas do verão de 1881 (M III 1).

1. Os fragmentos póstumos do verão de 1885 são atravessados por uma discussão aprofundada sobre o grau de certeza imediata que é possível extrair do cogito cartesiano. ${ }^{50}$

Spir distingue dois tipos de certeza: uma certeza imediata e uma certeza mediata. A primeira, naturalmente, deve ser tomada como base para a segunda e, portanto, como fonte do conhecimento em geral. A glória eterna de Descartes foi a de ter sido o primeiro a indicar para a filosofia o caminho da certeza imediata e de ter

49Sobre a leitura de Über die scheinbaren und die wirklichen Ursachen des Geschehens in der Welt (Halle 1884) e sobre a utilização de Drossbach nos fragmentos póstumos do período abril-julho de 1885, podemos nos referir ao interessante artigo de Rüdiger W. Schmidt ("Nietzsches DrossbachLektüre”, Nietzsche Studien, 17 (1988), pp. 465-477). É muito provável que Nietzsche já tivesse lido, durante o verão de 1881, um artigo de Drossbach intitulado Eine Untersuchung über die Wahrnehmbarkeit der Erscheinungen und die Unwahrnehmbarkeit der Wesen (Uma investigação sobre o caráter perceptivo dos fenômenos e o caráter não-perceptivo da essência), Philosophische Monatshefte, (11) 1875, pp. 403-419, 433-452, reeditado ulteriormente em apêndice no volume de 1884), pois, numa carta de 20/21 de agosto de 1881, Nietzsche solicitou a Overbeck o envio do décimo primeiro ano de Philosophische Monatshefte.

50 Para uma primeira análise da crítica nietzschiana do cogito cartesiano, pode-se consultar o artigo de Karl-Heinz Dickopp: "Zum Wandel von Nietzsches Seinsverständnis. African Spir und Gustav Teichmüller" (Zeitschrift für philosophische Forschung, 24 (Januar-März 1970), pp. 50-71), que tem o mérito de reconstruir e comparar os dois momentos (verão de 1881 e verão de 1885) e os dois interlocutores (Spir e Teichmüller) com quem Nietzsche dialoga. Essa é razão pela qual a análise de Dickopp é sem dúvida mais meticulosa que a de Funke (Funke, Gerhard. "Cogitor ergo sum", Sinn und Sein, Tübingen, 1960, p. 171) ou que a de Heidegger (Heidegger, Martin. Nietzsche, Pfullingen, 1961, t. II, p. 181). De qualquer modo, a crítica a Spir e Teichmüller é vista por Dickopp unicamente em relação ao desenvolvimento da "metafísica" da vontade de potência, e isso, em nossa opinião, não leva suficientemente em consideração a ambição nietzschiana de superar a metafísica mediante uma história genética do pensamento. 
D'Torio, P.

determinado a sua fonte no testemunho da consciência ${ }^{51}$. Mas a tentativa cartesiana, que Spir valoriza e que interpreta como vimos acima (ver p. 40), deve ser integrada de tal modo que seja permitido não somente 1) a certeza da existência de cada conteúdo da consciência, mas 2) também a certeza da existência dos objetos que a ela estão relacionados, e 3) a certeza das relações gerais entre esses objetos.

A natureza particular da ideia permite, segundo Spir, a passagem do interior da consciência ao mundo empírico, já que a ideia é uma imagem da consciência que é acompanhada pela fé na existência de objetos representados. ${ }^{52}$ Por outro lado, a passagem do objeto particular para as relações gerais entre os objetos é possível graças aos princípios lógicos que constituem a fonte da certeza racional de que falaremos a seguir.

Ocupemo-nos agora da discussão sobre o cogito cartesiano nas obras de Spir e Nietzsche.

51 “ A certeza imediata é, portanto, a fonte de toda certeza em geral. A primeira tarefa da filosofia consiste, assim, em buscar a certeza imediata". "Foi a glória eterna de Descartes ter sido o primeiro a enunciar com ênfase que a filosofia que merece esse nome deve começar pelo começo, isto é, pela certeza imediata, e ter descoberto, com uma intuição certeira, no conteúdo de nossa consciência a natureza atual da certeza imediata" (Spir, Afrikan. DW, I, pp. 26, 28). Encontra-se no exemplar de Nietzsche um traço ao lado do último parágrafo.

52 “Cf. Spir, Afrikan. DW I, p. 45; cf. também p. 47: “ Não há, assim, nenhum outro princípio ou fundamento da certeza do que a força de afirmação inerente às representações mesmas. Nunca poderiam nossas representações da crença e sua certeza vir do exterior, dos objetos" (Spir, Afrikan. DW, I, p. 47). A ideia de que o juízo é caracterizado pela fé na existência dos objetos foi recuperada muitas vezes por Nietzsche. Cf. por exemplo: MA I/HH I 18, KSA 2. 38-40, Nachlass/FP 26[65], KSA 11. 166; 40[15], KSA 11. 634 e $635 ; 7[4]$, KSA 12. 264.

46 | Cad. Nietzsche, Guarulhos/Porto Seguro, v.42, n.2, p. 11-60, maio/agosto, 2021. 
Spir, DW I, p. 26-27

Como se sabe, primeiramente Descartes manifestou, com a ênfase necessária para essa questão, que o pensamento, ou a consciência, é imediatamente certo de si mesmo. A existência do pensamento mesmo, assim ele argumentava, não pode ser negada ou duvidada, pois essa negação ou dúvida já são, elas mesmas, estados do pensamento ou da consciência; sua própria existência prova assim aquilo que elas contestam e lhes retira, portanto, aquele significado.
Nietzsche, Nachlass/FP 40[24], KSA 11. 640

Não se deve edulcorar ou amoldar a ingenuidade de Descartes, como, por exemplo, faz Spir.

A consciência é imediatamente certa de si mesma: a existência do pensamento não pode ser negada ou duvidada, pois essa negação ou dúvida já são, elas mesmas, estados do pensamento ou da consciência; sua própria existência prova assim aquilo que elas contestam e lhes retira, portanto, aquele significado" Spir I, 26. "Pensa-se", ergo existe algo, a saber, "pensamento". Foi esse o sentido de Descartes? Teichmüller p. 5 e 40 afirma. "Algo que é imediatamente certo de si mesmo" é um absurdo

Nessa passagem, Spir reinterpreta o cogito cartesiano como certeza imediata da existência de um conteúdo da consciência, de um pensamento. Em primeiro lugar, Nietzsche contesta que tenha sido nesse sentido que Descartes utilizou o célebre argumento. $\mathrm{Na}$ verdade, Descartes desejava chegar à demonstração da existência de uma res cogitans, tal como lembra Nietzsche: "NB. Pensa-se: logo, há algo que pensa" — assim desemboca o argumento de Descartes —-, mas a realidade de um pensamento não é o que queria Descartes. Ele queria ir além da "imaginação" para chegar a uma substância que pensa e se imagina" (Nachlass/FP 40[22], KSA 11.639).

Sobre essa interpretação de Descartes, Nietzsche reenvia ao livro de Teichmüller, que cita a objeção de Gassendi a Descartes, segundo a qual a validade do cogito, ergo sum depende da frase mais geral «Tout ce qui pense existe» (e certamente não se pode fazer o contrário, isto é, tentar demonstrar o caso geral partindo do caso particular, como diz Descartes em sua resposta a Gassendi) ${ }^{53}$; ademais, Teichmüller nota, sempre sobre o tema das objeções feitas a Descartes por seus contemporâneos, que já se deve saber o que é a

53 Cf. Teichmüller, Gustav. $O$ mundo real e o aparente, cit., p.40 
existência antes de poder deduzi-la do cogito, ergo sum ${ }^{54}$. Descartes respondeu, sobre o segundo ponto, que ninguém pode ser idiota a ponto de dever aprender o que é a existência antes de poder concluir e afirmar que ele existe. Segundo Teichmüller, pode-se deduzir dessa resposta que "Descartes jamais justificou esse conceito, que ele utilizou como se cada um o possuísse em sua consciência" e, em conclusão, que "Descartes não possuía um conceito de ser" (p. 5-6). Com efeito, a investigação de Teichmüller exclui do «Topik der Idee des Seins» [Tópica da ideia de ser] diferentes abordagens da problemática ontológica, que se privilegiava antigamente. $\mathrm{O}$ conceito de ser, segundo Teichmüller, não pode se encontrar nas intuições ou nos supostos objetos, nem nas atividades da alma ou da consciência e, "como ninguém gostaria de considerar as puras sensações do assim chamado sentido interno, nem a consciência de si imediata e particular, como o lugar lógico do conceito de ser, resta-nos a intuição intelectual (quer dizer, o domínio das ideias) que é traduzido em conceitos pela dialética" (p. 32).

A intuição intelectual, caracterizada por uma visão imediata do real ("O que se vê com um olhar do espírito também é reconhecido intuitivamente"), é o único domínio apto a acolher a problemática ontológica e a abrir uma investigação que conduz à autoconsciência enquanto domínio de manifestação e única fonte do conceito de ser. ${ }^{55}$

Nietzsche sobrepuja as críticas que Teichmüller dirige a Descartes, antevendo que não somente deve-se saber antes o que

\footnotetext{
54 Cf. Teichmüller, Gustav. op.cit., p. 5: "Descartes começou brilhantemente explicitando tudo como duvidoso para, daí, investigar como se não houvesse nada de fixo. Mas assim que ele colocou o problema, ele então concluiu novamente que eu, que duvido, sou, como se ele já soubesse o que seria o ser, e pudesse, simplesmente, predicá-lo"; pp. 40-41: "Descartes estava na situação na qual se encontrava a maioria dos filosofadores, a saber, devido ao longo uso da palavra "existência", ele deveria já saber o que é "existir", não precisando oferecer uma elucidação desse conceito".

55 Teichmüller, Gustav. op. cit., p. 36 e p. 73: "Na autoconsciência nós temos a única fonte de nosso conceito de ser [...] Nós inferimos do ser todas as outras coisas; somos conscientes imediatamente de nosso próprio ser e justamente esse saber de nós mesmos e de nossas ações e seus conteúdos é tudo que entendemos como ser, e não há outra fonte de conhecimento para esse conceito".
}

48 | Cad. Nietzsche, Guarulhos/Porto Seguro, v.42, n.2, p. 11-60, maio/agosto, 2021. 
é o ser para deduzir o cogito do sum, mas deve-se também saber o que é o pensamento e o saber; deve-se, além disso, ter fé na lógica, no ergo, e no fato de que isso que nós percebemos é um esse e não um fieri. A dúvida cartesiana surge, portanto, sobre uma série de certezas, e o cogito, em todo caso, pode ser, na melhor das hipóteses, uma certeza mediata. ${ }^{56}$

De resto, Nietzsche remete a falsa suposição contida no cogito a uma sugestão inconsciente da língua, a um antigo preconceito escondido entre as funções gramaticais que são ainda as coisas nas quais se crê mais firmemente e das quais nunca poderemos desconfiar o bastante. (cf. Nachlass/FP 40 [27], KSA 11. 643).

O que me separa fundamentalmente dos metafísicos é isto: eu não lhes concedo que o "eu" é isto que pensa: em vez disso, eu tomo o eu mesmo enquanto uma construção do pensamento, da mesma ordem que a "matéria", "coisa", "substância", "indivíduo", "fim", "número": portanto, somente enquanto ficção regulativa, por meio da qual uma espécie de permanência, e consequentemente "cognoscibilidade", é colocada, colocada poeticamente, num mundo do vir-a-ser. A crença na gramática, no sujeito e no objeto linguísticos, nas palavras de atividade, até agora subjugaram a metafísica: eu ensino a renunciar a essa crença. O pensamento coloca primeiro o eu: mas até agora se acreditou, como o "povo", que no "eu penso" é possível encontrar algo como uma certeza imediata e que esse "eu" era a causa dada do pensamento, por meio da qual nós "compreendemos" por analogia todas as outras relações de causalidade. Apesar dessas ficções serem costumeiras e indispensáveis, isso não prova nada contra seu caráter de

56 Nachlass/FP 40[23], KSA 11. 639 e 640, mas sobretudo o aforismo 16 de Para além do bem e mal. Completamos a citação iniciada acima acerca da comparação com os textos de Spir e Teichmüller; eis a parte final de 40[24]: "Não há certezas imediatas: cogito, ergo sum pressupõe que se sabe o que é "pensar" e, segundo, o que é "ser": se o est (sum) fosse verdadeiro, há uma certeza, sustentada sobre dois juízos corretos, que acrescenta a certeza de que se tem o direito em geral à dedução, ao ergo - logo, de modo algum uma certeza imediata. A saber: no cogito não é somente inserido um processo que seria simplesmente reconhecido — isso não faz sentido! - , mas um juízo que se trata de tal e tal processo, e quem, por exemplo, não soubesse diferenciar pensar, sentir e querer, não poderia constatar o processo. E no sum ou o est coloca-se ainda uma imprecisão conceitual de que, com isso, nem o "fit" nem o "isso foi" foram refutados. "Aconteceu algo" poderia ser colocado no lugar de "ali há algo, ali algo existe, algo esta lá"). 
D'Torio, P.

invenção poética: algo pode ser condição da vida e ser, apesar disso, falso. Nachlass/FP 35[35], KSA 11.526.57

Se Nietzsche, em 1881, considerava o ser que representa as coisas (e, portanto, não o cogito, mas antes o cogitat, ou ainda melhor, o cogitatur) como o único tipo de ser ao qual nós temos acesso, durante a segunda metade dos anos 1880 ele acentua seu ceticismo e afirma que a via de Descartes, pela qual "não se chega a uma certeza absoluta, mas somente a uma grande fé", 58 não é praticável. As críticas de Nietzsche, apesar de dirigidas principalmente ao "eu penso" cartesiano e spiriano, não poupam a intuição intelectual de Teichmüller, que não é capaz de fornecer a certeza imediata — pois a "certeza imediata" não passa de uma contradictio in adjecto.

O grande perigo reside na hipótese de que haveria um conhecimento imediato (longo, um "conhecer" no sentido forte!). Teichmüller p. 35. Isto deveria ser algo, não sujeito, não objeto, não força, não matéria, não espírito, não alma: - poderiam me dizer que uma coisa dessas se assemelharia a uma quimera? Eu acredito nisso mesmo: e seria terrível se assim não o fosse! (Nachlass/FP 40[30, 31], KSA 11.644).

2. Se, de um lado, Nietzsche critica a existência disso que Spir chamava "certezas imediatas em matéria de fato", de outro lado ele também ataca as certezas imediatas em matéria de razão, quer dizer, as leis lógicas, os conceitos a priori, o conceito de incondicionado

\footnotetext{
57 A ideia de que o eu e a persistência são produtos do pensamento e ficções reguladoras indispensáveis à existência já foi formulada em 1881 (cf. Nachlass/FP 11[325] KSA 9.567 e 568 ver supra, p. 43, sq.). Por outro lado, a crítica da fé na gramática é típica desse período e se encontra em muitos fragmentos póstumos e aforismos (cf. Nachlass/FP 40[11, 16, 20, 27], KSA 11.632, 633, 635, 636638, 643); 6[13], KSA 12.237 e 238; 10[158], KSA 12.490 e 491; JGB/BM 16,17, 20, 34, 54, KSA 5.29-31, 34, 52-54, 73), até o famoso "Temo que não nos livraremos de Deus, pois ainda acreditamos na gramática..." em Crepúsculo dos ídolos (GD/CI, A “razão" na filosofia, 5, KSA 6.78).
}

58 Nachlass/FP 10[158], KSA 12.549; cf. também JGB/BM 16, KSA 5.29 e 30.

50 | Cad. Nietzsche, Guarulhos/Porto Seguro, v.42, n.2, p. 11-60, maio/agosto, 2021. 
de Spir, o conceito de ser de Teichmüller e, sobretudo, ele contesta a legitimidade de um alcance ontológico desses conceitos.

Teichmüller defende que as coisas do mundo exterior e os estados interiores não são conhecimentos imediatos e devem ser deduzidos a partir do conceito de ser, que é o único conceito que nos é dado imediatamente pela "intuição intelectual". ${ }^{99}$ Em outras palavras, devemos, antes de tudo, possuir o conceito de ser para poder remontar, por meio de um silogismo, à existência real do mundo dos fenômenos.

Spir, igualmente, defende que as leis físicas de associação de representações não bastam para produzir juízos e raciocínios. A simples aparição de um conteúdo em minha consciência não basta para produzir um conhecimento: ela deve ser acompanhada pela afirmação ou pela garantia de "que um objeto correspondente existe realmente" (p. 77). Isso significa que, nesse nível, devem intervir as leis lógicas, inatas no sujeito, "regras primitivas do conhecimento, princípios de afirmação de natureza lógica e não física" (p. 79). Essas leis lógicas são reduzidas por Spir ao conceito fundamental do incondicionado, único fundamento de nosso conhecimento dos corpos.

Por tudo isso, não há dúvida de que nosso conhecimento dos corpos está fundamentado numa lei do pensamento, não derivada da experiência, e essa lei não pode ser outra coisa senão um conceito do incondicionado, uma disposição interior do sujeito que pensa todo objeto em si enquanto incondicionado ou como substância". (Spir, Afrikan. DW, I, p. 147-148). ${ }^{60}$

59 Cf. Teichmüller, Gustav. op. cit, p. 73, cit. supra, nota 55.

60 No início de sua obra, Spir caracterizou assim a função lógico-ontológica do princípio de identidade: "Essa lei fundamental do pensamento, que condiciona o conhecimento dos corpos, e que encontra sua expressão no princípio de identidade, um conceito originariamente inerente a nosso pensamento da essência própria e incondicionada das coisas, que não se conforma com todos os dados da experiência — pois a experiência não oferece nada de incondicionado — , mas que, justamente por essa inconformidade, atesta sua validade objetiva. Nisto esse conceito prova ser o princípio comum da lógica e ontologia”) (Spir, Afrikan. DW, I, p. 30-31).

Cad. Nietzsche, Guarulhos/Porto Seguro, v.42, n.2, p. 11-60, maio/agosto, 2021. | 51 


\section{Nietzsche responde que não é necessário conhecer a natureza do ser para perceber o ser das coisas, bastando crer que se conhece. Desse modo, Nietzsche enfraquece o status do conceito de ser, do incondicionado, cuja existência não é condição necessária para o conhecimento da realidade, como desejavam Spir e Teichmüller.}

\section{Teichmüller, Die wirkliche und die scheinbare Welt, p. 25}

Mas é uma inferência quando explicamos as assim chamadas coisas como existentes, pois já temos de saber de antemão que natureza (terminus medius) tem o ser (term. major), para poder adjudicar ou negar esse conceito às coisas, assim como já temos de saber corretamente que características são próprias à Antiguidade ou ao Cinquecento, quando ousamos classificar uma descoberta de tal ou tal modo ${ }^{61}$.

$$
\text { Spir, DW I, p. } 76
$$

Assim que virmos que pertence à essência do sujeito relacionar o conteúdo que lhe ocorre aos objetos, formando juízos, segundo sua constituição, sobre a existência e natureza dos objetos, não apenas imediatamente como também mediatamente, por meio de inferências. - fica claro que as leis mesmas do sujeito cognoscente implicam uma relação necessária com os objetos e sua concepção, que já estas mesmas não podem ser nada mais que princípios universais sobre objetos, isto é, uma necessidade interna de acreditar em algo como objetos $^{62}$.

Tais espécies de leis se chamam leis lógicas e estas são diferentes, segundo a essência íntima, das leis objetivas, físicas, às quais também pertencem as leis de associação.
Nietzsche, Nachlass/FP 40[12], KSA 11. 633

Teichmüller p. 25 "é uma inferência quando explicamos as assim chamadas coisas como existentes, pois já temos de saber de antemão que natureza (terminus medius) tem o ser (term. major), para poder adjudicar ou negar esse conceito às coisas". Ao contrário, digo eu: "pensar saber".

"Leis lógicas" em Spir I p. 76 definidas como "princípios universais de asserções sobre objetos, isto é, uma necessidade interna de acreditar em algo como objetos"

61 Teichmüller precisa também a forma do silogismo: "Tudo que aprece de tal e tal maneira" (terminus medius), é real (major);/ Este fenômeno aqui (minor) corresponde às condições dadas (medius);/Este fenômeno é real" (Teichmüller, op. cit., p. 25, nota).

62 Nietzsche faz dois traços na margem de seu exemplar, nas últimas quatro linhas.

52 | Cad. Nietzsche, Guarulhos/Porto Seguro, v.42, n.2, p. 11-60, maio/agosto, 2021. 
Nietzsche defende que esses princípios a priori, o conceito de "ser" e o "incondicionado", necessários para oferecer valor objetivo ao fluxo de representações no sujeito cognoscente, são ficções reguladoras (regulative Fiktionen) às quais não se pode atribuir existência, erros fundamentais nascidos de uma falsa interpretação do vir-a-ser e, consequentemente, incorporadas como condição de sobrevivência de nossa espécie (cf. a última parte de Nachlass/FP 40[12], KSA 11.633).

O confronto entre Nietzsche, Spir e Teichmüller está fundado, assim, sobre o status ontológico do a priori. De um lado, a formulação lógico-ontológico, que considera o a priori como única via de acesso à verdadeira realidade do mundo; de outro, uma formulação genéticoevolutiva que considera o a priori uma ficção reguladora, como erro original.

Nietzsche escreve: "Juízos sintéticos a priori são possíveis, mas eles são - juízos falsos", ${ }^{63}$ são juízos grosseiros, frutos de épocas da ciência primitiva. A questão kantiana: "como são possíveis juízos sintéticos a priori?", é substituída por Nietzsche por uma outra questão: "por que a fé nesses juízos é necessária?" (JGB/BM 11, KSA 5.25).

Naturalmente, se a existência do mundo real depende do conceito de ser, a filosofia não deve se ocupar com coisas sensíveis, mas com formas a priori que tornam possível a manifestação da experiência para o sujeito. Eis o que afirma Teichmüller: “Deve-se

63 Nachlass/FP 34[171], KSA 11. 477. Como apontou acertadamente R. Schmidt, essa anotação é retirada de um comentário marginal que Nietzsche inscreveu na página 9 do livro de Drossbach, Sobre as causas aparentes e reais do processo no mundo, onde Drossbach discute a possibilidade de uma união dos fenômenos por juízos sintéticos enquanto condição de possibilidade da experiência. Nietzsche comenta: "O juízo sintético é um juízo falso" (Cf. Schmidt, Rüdiger W. "Nietzsches Drossbach-Lektüre", cit. p. 467). A consciência de que os juízos sintéticos são substancialmente ilógicos e falsos é, de qualquer modo, uma constante no pensamento de Nietzsche. Ela remonta aos fragmentos póstumos de 1872 (cf. supra, p. 18), nos quais Nietzsche criticou a definição do juízo sintético contido em Pesquisa sobre a consciência e o pensamento de Spir, levando em consideração A linguagem como arte de Gerber. 
D'Torio, P.

notar que cabe à história da natureza e do homem as determinações empíricas; que a filosofia, porém, tem a ver somente com formas apriorísticas" (Teichmüller, op. cit., p. 187).

Talvez seja essa formulação, que suscitou o famoso fragmento de Nietzsche (escrito precisamente em Sils-Maria durante o verão de 1885, evidentemente em conexão com as problemáticas levantadas pelos textos que analisamos aqui), no qual, tendo refutado a análise do a priori, ele enxerga a filosofia enquanto a forma de história mais geral.

A filosofia, tal como ainda considero válida, enquanto a forma mais geral de história, como uma tentativa de descrever, de algum modo, o vir-a-ser heraclítico e abreviá-lo em signos (por assim dizer, traduzir e mumificar numa espécie de ser aparente (Nachlass/FP 36[27], KSA 11.562).

No fragmento póstumo 38[14] essa reflexão é elaborada em reação aos instintos atávicos dos filósofos, que não creem na evolução dos conceitos, mas confiam nos esquemas de pensamentos mais antigos e mais falsos, identificando signos da linguagem com a essência das coisas. A etimologia e a história da linguagem nos permitem perceber o vir-a-ser dos conceitos, sua formação e sua transformação, e é possível chegar à conclusão que: “Os conceitos mais gerais enquanto os mais falsos, precisam ser também os mais antigos. "Ser", "substância" e "incondicionado", "igualdade", "coisa": o pensamento inventou para si, original e antigamente, esses esquemas que, com efeito, contradizem fundamentalmente o mundo do vir-a-ser, mas que, primordialmente, em virtude do caráter obtuso e indiferente da consciência infante e ainda subanimal, parecia corresponder com esse mundo".

Não há ainda nenhum filósofo, segundo Nietzsche, que tenha feito uma verdadeira crítica dos conceitos. Pelo contrário, são justamente os filósofos que possuem mais dificuldades de se 
emancipar da fé na gramática, da crença segundo a qual os conceitos fundamentais e as categorias da razão pertencem ao domínio de certezas metafísicas. Somente uma história da gênese do pensamento pode demonstrar o valor da lógica e da filosofia metafísica: "Mesmo agora a maioria dos filósofos não suspeitou o que seria uma verdadeira crítica dos conceitos ou (como eu outrora designei) uma "história da origem do pensamento". (Nachlass/FP 6[13], KSA 12.237 e 238 e 40[27], KSA 11.643) ${ }^{64}$.

De um ponto de vista estritamente lógico, o conceito de incondicionado não é menos irrefutável. Com efeito, pode-se facilmente negar sua existência. Nietzsche, simples e lapidarmente, escreveu: "Do incondicionado não pode provir nada de condicionado. Agora, tudo que conhecemos é condicionado. Logo, não há incondicionado, é uma suposição supérflua." (Nachlass/FP 26[429], KSA 11.265).

Mas o problema é de natureza moral: ele concerne ao valor que se dá ao efêmero, à dor, à imperfeição. Por isso que Nietzsche escreve que o verdadeiro mundo dos metafísicos é uma "ilusão de ótica moral" e um produto da vida em declínio. Resumindo a discussão sobre o cogito cartesiano e sobre a função e valor do $a$ priori, Nietzsche julga a dúvida cartesiana como superficial e recusa o despotismo da deusa Razão, típico dos lógicos que creem no ser (Teichmüller) ou no incondicionado (Spir).

A crença na certeza imediata do pensamento é mais uma crença, não uma certeza! Nós inovadores somos todos opositores de Descartes e nos defendemos contra a frivolidade dogmática da dúvida. "Deve-se saber melhor duvidar do que Descartes!". Nós encontramos o inverso, um movimento de reação contra a autoridade absoluta da deusa "razão", onde existem homens profundos. Lógicos fanáticos foram levados ao caminho em que o mundo é

64 Nietzsche escreveu sobre a necessidade de uma história da gênese do pensamento no aforismo 16 de Humano, demasiado humano (cf. supra p. 32). 
D'Torio, P.

uma ilusão; e que o caminho para o "ser", para o "incondicionado", só é dado pelo pensamento. Inversamente, tenho deleite com o mundo, mesmo que ele tenha de ser uma ilusão; e o entendimento dos entendedores sempre foi hilário para homens mais completos". (Nachlass/FP 40[25], KSA 11. 641). ${ }^{65}$

A desconfiança ante o vir-a-ser, o temor do engano, a necessidade de encontrar um sólido e verdadeiro ponto de apoio — que Nietzsche reconhece também na vontade de se amparar no ideal (por exemplo, em F.A. Lange), que, no gosto moderno por objetividade (o naturalismo dos artistas parisienses), e que é sintoma de um desprezo de si-mesmo, de uma impotência de forças formadoras, a expressão intelectual de uma décadence fisiológica - encontram sua expressão mais significativa no fanatismo e na superstição dos filósofos críticos, que se agarram com força nos conceitos mais gerais e mais vazios, "a última fumaça da realidade que se evapora", ao invés de confrontar o mundo do vir-a-ser. ${ }^{66}$

Os conceitos mais elevados e os petit-faits, que somente em aparência são opostos, são, na realidade, duas expressões diferentes da fraqueza da força de vontade e da incapacidade de fazer frente

65 Cf. também Nachlass/FP 10[158], KSA 12.549. Provavelmente Nietzsche inclui Drossbach entre os "lógicos fanáticos". Drossbach qualificava a experiência sensível como "aparência vazia e ilusão" (leerer Schein und Trug), suscitando essa reflexão de Nietzsche: "O mundo do fenômeno "aparência vazia e ilusão", a necessidade de causalidade que estabelece conexões entre os fenômenos, assim como "ilusão e aparência vazia" — com isso é expresso a rejeição moral do ilusório e aparente. Devese ultrapassar isso. Não há coisa em si, tampouco absoluto conhecimento, o caráter perspectivístico, enganador, pertence à existência", Nachlass/FP 34 [120], KSA 11. 460 (cf. SCHMIDT, Rüdiger W. "Nietzsches Drossbach-Lektüre", p. 467 e sq.).

66 A impossibilidade de encontrar um fundamento sólido, que mergulhou Lange no desespero, é considerada por Nietzsche, no Nachlass/FP 25[318], KSA 11.94, como um efeito póstumo de um ponto de vista do escravo (Sklavengesichtspunkt); sobre o faitalisme enquanto indício da sensação de insegurança e desprezo de si-mesmo, típicas do mundo moderno, cf. Nachlass/FP 25[12, 164], KSA 11.13 e 14, 57 e 58; para os conceitos mais elevados, cf. Crepúsculo dos ídolos, A "razão" na filosofia, 4, KSA, 6.76 .

56 | Cad. Nietzsche, Guarulhos/Porto Seguro, v.42, n.2, p. 11-60, maio/agosto, 2021. 
à ausência de sentido do real ${ }^{67}$. Após 1885, numerosos fragmentos póstumos formulam, numa línguagem claramente derivada do neokantismo, e sobretudo de nossos três "lógicos fanáticos", Spir, Teichmüller e Drossbach, a oposição entre ser e vir-a-ser, mundo verdadeiro e mundo aparente, para reconduzi-la ao juízo moral sobre o valor do vir-a-ser. A filosofia metafísica aparece para Nietzsche como uma "grande escola de depreciação" e, com a moral e a religião, como um dos terrenos propícios à ideia de um "outro mundo", geradas pela fadiga de viver e certamente não pelo instinto da vida. ${ }^{68}$

Nos fragmentos póstumos da segunda metade dos anos 1880, nós não encontramos mais momentos de confrontação direta com Spir. Mas o conflito com a filosofia metafísica em geral (de Platão até Kant, Schopenhauer, os contemporâneos) continua, cada vez mais ríspido. Nietzsche procura desenvolver uma psicologia da metafísica, revelando as idiossincrasias e os preconceitos dos filósofos, como, por exemplo, "a hostilidade perigosa e cega dos filósofos diante dos sentidos", a vontade de fugir da dor, a sobrevalorização da razão enquanto fonte da revelação do em-si (mesmo se ela contrasta com o testemunho dos sentidos). ${ }^{69}$ A apreciação do permanente, o desprezo e ódio por tudo que passa, muda e se transforma, são sintomas de um enfraquecimento da força vital, são produzidos pelo esgotamento e o sofrimento, pelas angústias e necessidades de uma humanidade dominada há séculos pela moral.

67 Cf.: "A medida do grau de força de vontade é obtida sabendo até que ponto se pode dispensar o sentido nas coisas, até que ponto se suporta viver num mundo desprovido de sentido (...) Pois a força organiza o mais perto e o mais próximo" (Nachlass/FP 9[60], KSA, 12.366).

68 Cf.: "O filósofo que inventa um mundo racional, adequado à razão e às funções lógicas: - daqui provém o "mundo verdadeiro" (Nachlass/FP 14[168], KSA, 13.353).

69 Cf. o importante capítulo de Crepúsculo dos ídolos: A "razão" na filosofia, no qual Nietzsche resume magistralmente os numerosos fragmentos sobre esse tema contidos no Nachlaß dos anos oitenta: "Vocês me perguntam o que é a idiossincrasia nos filósofos?...Por exemplo, sua falta de sentido histórico, seu ódio contra a representação mesma de vir-a-ser, seu egipcismo"; cf. também Nachlass/ FP 8[2], KSA 12.327 e 328, 14[134], KSA 13.317-319. 
D'Torio, P.

Spir, DW I, p. 278

No âmbito do incondicionado reina uma calma perfeita, uma ausência completa de mudança, um ser-igual-a-si-mesmo transparente. Pois toda mudança é estranha à essência das coisas. Assim, no próprio incondicionado não pode ocorrer nenhuma mudança, mas também ele não contém o germe ou a causa da mudança no mundo empírico.
Nietzsche, Nachlass/FP 40[59], KSA 11.658

Ao contrário, a incerteza, a ambiguidade, o cambiante e a transformação, é nosso mundo, um mundo perigoso —: muito mais, certamente, que o mundo simples, iguala-si-mesmo, calculável, fixo, que até então os filósofos, como herdeiros dos instintos de rebanho e das valorações de rebanho, prestaram as maiores honras.

Um ultrapassamento da metafísica e de todas as filosofias do ser é necessário enquanto momento preparatório para a divinização do vir-a-ser. É somente após a eliminação do longo erro do mundo verdadeiro que incipit Zarathustra, mestre do eterno retorno, quer dizer, da filosofia que nega completamente o ser e atribui ao vir-a-ser eterno a verdadeira realidade.

Superação dos filósofos mediante destruição do mundo do ente: período intermediário do niilismo: antes de a força reverter os valores e divinizar, aprovar, o mundo em vir-a-ser, aparente, enquanto o único. (Nachlass/ FP, 9[60], KSA 12.367).

58 | Cad. Nietzsche, Guarulhos/Porto Seguro, v.42, n.2, p. 11-60, maio/agosto, 2021. 


\section{The four stages of Nietzsche's reading of Afrikan Spir}

Abstract: The work of Afrikan Spir is an important source to understand the discussion between Nietzsche and critical philosophy. He seeks to overcome the transcendental critique through a genetic investigation on the origin of concepts; at same time, tries to reveal the preconceptions and idiosyncrasies that hide behind the will to keep the separation between the phenomenal and noumenal worlds. The aversion to change, to the becoming, to the testimonial of the senses, the preference for logical truths and contradictory concepts constitute, according to Nietzsche, the specific form of superstition of the critical philosophers, of which Spir is the most prominent example.

Keywords: Spir, transcendental tradition, metaphysics, unconditioned.

\section{Referências}

DICKOPP, Karl-Heinz. "Zum Wandel von Nietzsches Seinsverständnis. African Spir und Gustav Teichmüller". Zeitschrift für philosophische Forschung, 24, Januar-März, 1970.

FUNKE, Gerhard.“Cogitor ergo sum”, Sinn und Sein. Tübingen: Niemeyer, 1960.

HEIDEGGER, Martin. Nietzsche. Pfullingen: Neske Verlag, 1961.

MEIJERS, Anthonie, "Gustav Gerber und Friedrich Nietzsche. Zum historischen Hintergrund der sprachphilosophischen Auffassungen des frühen Nietzsche", Nietzsche Studien, 17 (1988), p. 367-390.

NIETZSCHE, Friedrich. Die vorplatonischen Philosophen. Großoktavausgabe (GOA), vol. xIx. Leipzig: Naumann, 1901.

. Sämtliche Briefe. Kritische Studienausgabe (KSB). Berlim/ Nova York: Walter de Gruyter, 1986.

. Sämtliche Werke. Kritische Studienausgabe (KSA). Berlim/ Nova York: Walter de Gruyter, 1980. 
D’Torio, P.

OEHLER, Max. Nietzsches Bibliothek, Vierzehnte Jahresgabe der Gesellschaft der Freunde des Nietzsche-Archivs. Weimar, 1942.

SCHLECHTA, Karl e ANDERS, Anni. Friedrich Nietzsche. Von den verborgenen Anfängen seines Philosophierens, Stuttgart: Frommann, 1962.

SCHMIDT, Rüdiger. “Nietzsches Drossbach-Lektüre”, Nietzsche Studien, 17 (1988), pp. 465-477.

SCHOPENHAUER, Arthur. Die Welt als Wille und Vorstellung in Sämtliche Werke, Leipzig: Brockhaus, 1938.

SPIR, Afrikan. Denken und Wirklichkeit. Versuch einer Erneuerung der kritischen Philosophie, Leipzig: Findel, 1873, 2 vol., 1873).

. Denken und Wirklichkeit. Versuch einer Erneuerung der kritischen Philosophie, Leipzig: Findel, 1877.

. Forschung nach der Gewissheit in der Erkenntniss der Wirklichkeit, Leipzig: Förster \& Findel, 1869.

. Gesammelte Schriften, 4 vol., Leipzig 1883-85.

.Gesammelte Werke, 2 vol., Leipzig 1908.

. Pensée et Réalité. Essai d'une réforme de la philosophie critique, Lille: Tallandier, 1896.

TEICHMÜLLER, Gustav. Die wirkliche und die scheinbare Welt. Neue Grundlegung der Metaphysik, Breslau: Koebner, 1882.

Enviado: 10/09/2016

Aceito: 28/03/2017

60 | Cad. Nietzsche, Guarulhos/Porto Seguro, v.42, n.2, p. 11-60, maio/agosto, 2021. 